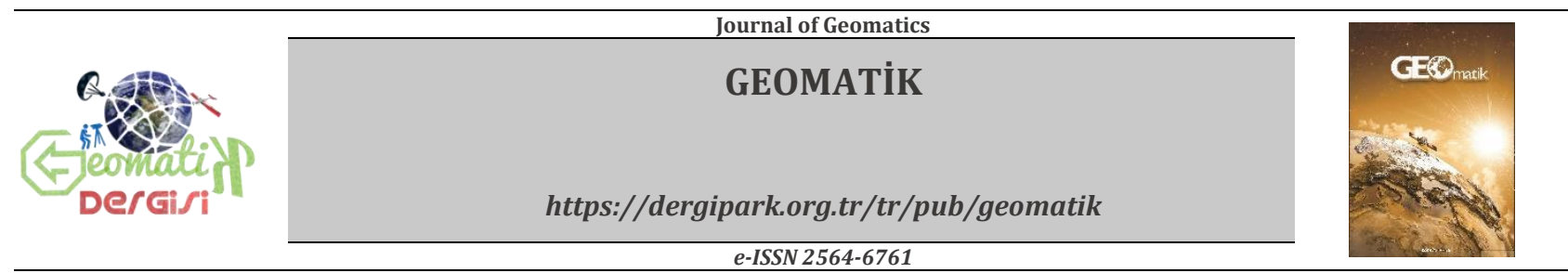

\title{
Türkiye Kırsal Arazi Kullanımına Yönelik Bir Konumsal Veri Altyapısının Modellenmesi
}

\author{
Muzaffer Can İBAN*1 \\ ${ }^{1}$ Mersin Üniversitesi, Mühendislik Fakültesi, Harita Mühendisliği Bölümü, Mersin, Türkiye
}

\author{
Anahtar Kelimeler \\ Konumsal veri altyapıları \\ TUCBS \\ TARBIL \\ INSPIRE \\ Kırsal arazi yönetimi
}

\begin{abstract}
ÖZ
$\mathrm{Bu}$ çalıșma, Türkiye için kırsal arazi kullanımını ilgilendiren bir konumsal veri altyapısının (KVA) oluşturulmasına yönelik olarak, sensör kullanımını ve her çeşit kırsal arazi kullanımı için gerekli öznitelikleri derleyen bir kavramsal çerçeve sunmaktadır. Makale ilk olarak, ülkemizdeki ulusal KVA girișimlerini ve sensör tabanlı tarımsal izleme çalışmalarını incelemektedir. Önerilen model, tarım arazileri, mera arazileri ve orman arazileri gibi tüm kırsal arazi kullanımını, Toprak Koruma ve Arazi Kullanımı Kanunu ve diğer mevzuatlar ile uyumlu bir şekilde bütünleștirmektedir. Bu kavramsal şema aynı zamanda, gıda güvenliği veritabanları (organik ve iyi tarım uygulamaları), tarım dışı arazi kullanımı başvuruları ve yerel/Avrupa destekli tarımsal hibeleri yönetmek amaçlı oluşturulan sistemlerle (APTS) bağlantılı olarak hazırlanmıștır. Bu kavramsal șemaya standartlaștırılmıș bir görünüm sağlamak adına, Bütünleșik Modelleme Dili (UML) sınıf diyagramları kullanılmış ve kullanılan özniteliklerin, veri tiplerinin ve kod listelerinin açık tanımlamalarının yapıldığı bir veri sözlüğü eklenmiştir. Bu kavramsal model, APTS, ISO 19156 Uluslararası Standart Kataloğu ve INSPIRE veri temaları standartlarını desteklemektedir. Ancak; sürdürülebilir kalkınma için kırsal alanların bir bütün olarak yönetilmesi amacıyla yerel bir anlayıșı da beraberinde getirmektedir. Modelin özgün nitelikleri, ülkemizdeki tarımsal izleme projesinin (TARBİL) sensör çeşitliliğini zenginleştirmesi ve TUCBS için kırsal arazileri ilgilendiren tematik veri şemasını sunmasıdır.
\end{abstract}

\section{Modelling a Spatial Data Infrastructure towards Turkish Rural Land Use}

\author{
Keywords \\ Spatial data infrastructure \\ TUCBS \\ TARBIL \\ INSPIRE \\ Rural land management
}

\begin{abstract}
This study provides a conceptual model of a Turkish rural spatial data infrastructure (SDI) that combines the sensor usage and required attributes for all sorts of rural lands. The article initially reviews current enterprises to a national SDI and sensor-driven agricultural monitoring studies in Turkey. The suggested model integrates all rural land use types, such as agricultural lands, meadowlands and forest lands in accordance with the Soil Protection and Land Use Law and other related legislation. This schema is associated with food security databases (organic and good farming practices), nonagricultural land use applications and monitoring systems for local and European farmer subsidies (LPIS). To provide a standard visualization of this conceptual schema, the Unified Modeling Language (UML) class diagrams are used and a supplementary data dictionary is prepared to make clear definitions of the attributes, data types and code lists used in the model. This conceptual model supports the LPIS, ISO 19156 International Standard catalogue and INSPIRE data theme specifications; however, it also provides a local understanding that enables to manage rural lands holistically for sustainable development. Original qualifications of this model are that not only it suggests an expansion for the sensor variety of Turkish agricultural monitoring project (TARBIL), but also it specifies a rural theme for Turkish National SDI (TUCBS).
\end{abstract}




\section{GíRiş}

Konumsal Veri Altyapıları (KVA), insanoğlunun araziyle olan ilişkisini, doğal kaynakların yönetimini, planlanmasını ve gerekli politikaların belirlenmesini, bu amaçlara hizmet eden verilere erişilmesini sağlayan karmaşık sayısal ortamlar bütünüdür. KVA'lar, veriyle ilgili bütün paydaşların birlikte çalışabildiği ve ortak amaçlar için teknolojiden faydalanılan bütünleşik bir hizmet girişimidir. KVA çalışmaları kapsamında, veri üretiminin kontrolü sağlanır ve verilere bir standartın kazandırılmasıyla veri tekrarları önlenir (Coleman ve McLaughin, 1998; Hjelmager ve diğerleri, 2008; Rajabifard ve Williamson, 2001; Sang ve diğerleri, 2005).

1992 yılında Amerika Birleșik Devletleri'nde ilk kez dile getirilen 'Ulusal Bilgi Altyapısı' kavramı ile birlikte küresel, ulusal ve bölgesel düzeyde KVA girișimleri hız kazanmıştır. Ülkeler, KVA girișimlerini oluşturmuş ve bunlardan bazıları, internetten erişilebilir metaverileri kullanıma açmıştır. Uluslararası Standartlar Organizasyonu (İng. International Standards Organisation - kis. ISO) ve Açık Coğrafi Bilgi Konsorsiyumu (İng. Open Geospatial Consortium - kı. OGC) gibi uluslararası kurumlar da, KVA standartlarını geliştirmek ve etkin kullanımını sağlayacak teknolojik altlığı hazırlamak amacıyla çok sayıda girişimde bulunmuştur (Aydınoğlu, 2009; Aydınoğlu ve Yomralıŏlu, 2009).

Avrupa Birliği'nin 1990'lı yıllarda yaptığı çalışmalardan elde edilen deneyimler ve bu çalışmalarda coğrafi / konumsal bilginin kullanımının öneminin ortaya atılması, Avrupa Birliği'ne özgü bir KVA girișiminin kurulması ile sonuçlanmıştır (İng. Infrastructure for Spatial Information in Europe - kis. INSPIRE). Buradaki amaç, yasal bir direktif vasıtasıyla Avrupa'nın çevre politikalarını destekleyecek konumsal verilerin bütüncül bir çerçevede çalışmasını sağlamaktır. INSPIRE Direktifi, verinin varlığı, birlikte çalışılabilirliği, coğrafi kapsamı ve erişimi konusunda yoğun bir içeriğe sahiptir. Direktifin çekirdeğini oluşturan konumsal veriyi elde etmek için yapılması gereken gözlemler ve ölçümlere ilişkin 'Çevresel Gözlem Hizmetleri' (İng. Environmental Monitoring Facilities) adında teknik bir rehber bulunmaktadır. $\mathrm{Bu}$ rehber sayesinde, kullanıcılar ekosistem parametreleri ile ölçüm ve gözlemler arasındaki konumsal ilișkiyi kurabilmektedir. INSPIRE Direktifi, farklı türdeki 24 adet veri setinin bütünleştirilmesini ön gören 3 adet ek doküman (İng. Annex I, II ve III) yayınlanmıştır (Aydınoğlu, 2009; European Commission, 2007; Masser ve Crompvoets, 2015; Pashova ve Bandrova, 2017).

ISO'nun hazırladı̆̆ı ISO 19156:2011 Coğrafi Bilgi - Gözlemler ve Ölçümler (İng. Geographic Information - Observations and Measurements) adl standart metni de, gözlemler ve gözlemler esnasında elde edilen konumsal özellikleri tanımlayan bir kavramsal şema ortaya koymaktadır. Bu standart, OGC tarafından yürütülen 'Sensör Ağı Etkinleștirme' çalışmasından (İng. Sensor Web Enablement) türetilerek, her türlü sensör tipiyle gözlem ve ölçüm yapılmasını da desteklemektedir (ISO TC 211/SC, 2011; Kotsev ve diğerleri, 2018).

Arazi İdaresi Temel Modeli (İng. Land Administration Domain Model - kıs. LADM) ise, arazi yönetimi sistemlerinin yazılım uygulamalarına ilişkin küresel bir standart oluşturan ve paydaşiar arasındaki anlamlı veri değișimini yöneten bir çalışmadır. LADM, her türlü ölçmeye ve kadastroya ilişkin veriyi, hukuk düzenindeki tüm haklar, kısitlamalar ve sorumluluklar ile birlikte irdeler (Lemmen, van Oosterom ve Bennett, 2015; van Oosterom ve Lemmen, 2015). Bunun yanı sıra, Arazi Parseli Tanımlama Sistemi (Tr. kıs. APTS - Ing. Land Parcel Identification System - kls. LPIS), Avrupa Ortak Tarım Politikası (İng. Common Agriculture Policy kıs. CAP) çerçevesinde çiftçilere verilen tarımsal hibelerin yönetilmesini amaçlamaktadır. APTS sayesinde karar vericiler, tarımsal hibeye uygun görülebilecek olan tarım parsellerine ilişkin kayıtları haritalara aktarır ve görüntüler. (Inan ve diğerleri, 2010; Sagris, Wojda, Milenov ve Devos, 2013).

INSPIRE Direktifi'nin beraberinde getirdiği süreçlerden elde edilen deneyimler, ulus ve kıta geneli KVA'ların oluşturulması esnasında veri bütünleştirilmesi ve birlikte çalışılabilirlik adına ortak bir dilin geliştirilebileceği sonucunu doğurmuştur. Ancak, veri tanımlamaları yerel uygulamaların gerek duyduğu detay seviyesine de inmek zorundadır (Tóth ve Kučas, 2016). Dolayısıyla, yerel ölçeği de ilgilendirebilecek uygulamalarda bu veri tanımlamalarının genişletilmesi ya da özelleştirilmesi söz konusu olabilir. Bir başka deyişle, veri standartlarını belirleyen çerçeve her ne kadar küresel olarak düşünülse de, araştırmacıların ve karar vericilerin kendi ihtiyaçları ve ellerinde bulundurdukları mevcut veri setleri de bu standartların içeriğini belirler (Charvat ve diğerleri, 2018; Řezník ve diğerleri, 2015).

\section{1 Ülkemizdeki KVA Girişimleri}

2005 yılında, 36 numaralı Eylem Planı içerisinde ise, Türkiye Ulusal Coğrafi Bilgi Sistemi (kıs. TUCBS) kavramından ilk kez söz edilmiş ve Eylem-47'de belirtilen hususlar çerçevesinde bir TUCBS vizyonu oluşturulmaya çalışılmıştır. Buna göre, veri ve standartları, teknik altyapı, idari ve yasal altyapı ile ilgilenen çalışma komisyonları kurularak, ortak bir ulusal KVA'nın içeriğinin nasıl olması gerektiği, bu KVA'nın oluşturulması adına izlenecek politikaların neler olacağl, veri standartlarının nasıl tanımlanacağı, kurumların elinde hâlihazırda bulunan veri envanterlerine ilişkin metaverileri nasıl hazırlaması gerektiği, diğer kurumlarla veri paylaşımının nasıl olacağına işaret eden stratejik doküman olușturulmuștur (Aydınoğlu, 2009; Aydınoğlu ve Yomralığlu, 2009; Sani, 2013). 
TUCBS çalışmaları, 2011 yllında "644 sayılı Kanun Hükmünde Kararname" ile Çevre ve Șehircilik Bakanlığı'nın ve ona bağlı olarak Coğrafi Bilgi Sistemleri Genel Müdürlügü'nün kurulması ile hız kazanmıștır. 2012 yllında, bu genel müdürlüğün yürütücülüğünde ve TÜRKSAT A.Ş. - İstanbul Teknik Üniversitesi Teknokent A.Ş. yükleniciliğinde "TUCBS ve Türkiye Kent Bilgi Sistemi Standartlarının Belirlenmesi (TRKBISS)" projeleri yürütülmüștür. Bu projeler kapsamında, ulusal bir veri değişim formatı oluşturularak, on adet temel konumsal veri teması olușturulmuștur (adres, bina, tapu/kadastro, idari birim, ulaşım, hidrografya, arazi örtüsü, ortofoto, topoğrafya ve jeodezi) (Çevre ve Şehircilik Bakanlığı, 2012).

TUCBS Veri Modeli, ortak olarak kabul edilen ve farklı sektörlerdeki kullanıcıların gereksinimlerine yanıt verebilecek bir veri standartı oluşturmayı hedeflemiştir. Bu sebeple TUCBS, uluslararası standartlarla (OGC, ISO, INSPIRE vb.) ilintili olarak oluşturulmuş ve sektör özelinde oluşturulmuş diğer bilgi sistemleriyle de veri değişimi için bir altllkla da donatılmıştır (Çevre ve Şehircilik Bakanlığı, 2012).

\subsection{Problemin Tanımı}

Türkiye'de arazi yönetimi anlayışı ve ona bağlı olarak arazi kullanımı sorunlarının çözümüne yönelik çalışmaların ivme kazanması, mevzuatımızdaki iki büyük değişiklikle ortaya çıkmıştır. Bunlardan birincisi 2005 yılında yürürlüğe giren, yıllar içerisinde bazı maddelerinde değişiklik yapılan ve nihayetinde uygulama yönetmeliklerinin yürürlüğe girdiği "5403 sayılı Tarım Alanlarının Korunması ve Arazi Kullanımı Kanunu'dur". Bu Kanun ile toprağın korunması ve geliştirilmesi, tarım arazilerinin sinıflandırılması, yeter gelirli tarım arazilerinin tespit edilmesi ve sürdürülebilir kalkınma ilkelerine uygun, planlı arazi kullanımının gerçeğe dönüştürülmesi hedeflenmektedir (Resmi Gazete, 2005). Diğeri ise, 2012'de yürürlüğe giren ve 2014 yllında idari uygulamaya tabi tutulan 6360 sayılı "Yeni Büyükşehir Kanunu'dur". Bu Kanun, büyükșehir belediyelerinin yönetimini il sınırına çekmektedir (Resmi Gazete, 2012). Dolayısıyla, büyükșehir belediyelerinin hem kırsal, hem de kentsel yerleşimlere hizmet götürme zorunluluğu doğmuştur. Büyükşehirlerin, ilin bütününü planlama ve planlarını uygulama sorumluluklarının doğmasıyla, aslında "arazi yönetimi ve kullanımı idari birimleri" büyükșehir belediyeleri olmuştur.

Bu yasal reformların ardından karar vericilerin il geneli arazi kullanımını, özellikle de kırsal arazi kullanımını nasıl yöneteceği sorgulanmaya açık hale gelmiştir. Arazi yönetimi anlayışında kentsel ve kırsal alanların sürdürülebilir kullanımını ve yönetimini sağlamak ise mevcut KVA'lar düşünüldüğünde oldukça zorlayıcıdır. Bu bağlamda, kırsal ve kentsel arazi kullanımını TUCBS bünyesinde zenginleştirme güdüsü ön plana çıkmaktadır.
Aydınoğlu çalışmasında (2009, s. 228) arazi örtüsü ve kullanımı verilerinde kurumlarımız tarafından farklı yöntemlerin ve lejantların kullanıldığını vurgulamaktadır. Yerel ölçekten ulusal ölçeğe doğru genişleyecek şekilde, arazi örtüsü ve kullanımı sinıflarının ve standartlarının belirlenmesine işaret etmektedir. Aynı çalışmada Aydınoğlu (s.230), yerel ölçekte belirlenmiş konumsal veri ihtiyaçlarının il ölçeğinde (bir diğer deyişle, günümüzün büyükşehir belediye sınırlarını da kapsayacak şekilde) hazırlanacak bir uygulamaya doğru bütüncülleştirilebileceğini ve genelleștirilebileceğini hatırlatmaktadır.

İnan (2010, s. 147) ise kırsal arazi yönetimine vurgu yaparak, mevcut APTS yaklaşımının tarımsal desteklerin yönetimi açısından yeterli olduğunu; ancak bütünleșik bir kırsal arazi yönetimi açısından eksiklikler barındırdığını belirtmiş̧ir. Gerçekten de, APTS çalışmaları kapsamında kullanılan arazi kullanımı / örtüsü sınıflandırma sistemleri, tarım arazilerinin anlaşılması için gereken detaylı toprak sınıflaması anlayıșından uzaktır. Aynı çalışmada (s.159) 5403 sayılı yasanın hükmettiği faaliyetleri destekleyecek KVA çalışmalarının kırsal arazi yönetimine katkı yapacağı öne sürülmektedir. Taşkanat'a ait bir çalışma, kırsal arazi yönetiminin gerekliliklerini esas alan bir KVA ve standardizasyon çalışmasının yapılmasının TUCBS için bir zorunluluk olduğunu savunmaktadır (2016, s. 87).

\subsection{Türkiye Tarımsal İzleme ve Bilgi Sistemi Projesi (TARBIL)}

Tarımsal İzleme ve Bilgi Sistemi Projesi (TARBILL), 2008 yılında başlatılan çalışmalar neticesinde Gıda Tarım ve Hayvancılık Bakanlığı, Türkiye İstatistik Kurumu (TÜIK), Orman ve Su İșleri Bakanlığı ve İstanbul Teknik Üniversitesi Uydu Haberleșmesi ve Uzaktan Algılama Merkezi (UHUZAM) arasında sağlanan protokol ile bir veri füzyonu projesi olarak karşımıza çıkmaktadır. Uydulardan ve yerden alınan verileri, verimli bilgiye dönüștüren bir mekanizma kurmayı hedeflemektedir. Türkiye genelinde tesis edilmiş istasyonlardan elde edilen veriler, UHUZAM'da toplanarak, aynı merkezden indirilen uydu verileri ile birleştirilmektedir. Ülke sathında 2014 yllı itibariyle \%80'lik bir alan kaplanmıştır. TARBİL kapsamında araziye aplike edilen sensörlerle elde edilen kayitlar ve uydu gözlem verileri, bir bulut ortamında saklanarak, mobil teknolojiler aracilığıyla tarımda birey-makine-teçhizat bütünleştirilmesi yoluna gidilmiştir. $\mathrm{Bu}$ istasyonlardan anlık olarak alanın meteorolojik verileri, bitkilerin fenolojik evreleri ve olası hastalık durumları takip edilmektedir. (Durmuş, Güneş, Kırcı ve Üstündağ, 2015; Sönmez, Üstündağ, Bağış ve Çetin, 2015; Üstündağ ve Şentürk, 2015; Yazar, Özelkan ve Üstündağ, 2014).

\%100 yerli tasarlanmış bir platform olan TARBİL, tarımı yönetirken ihtiyaç duyulabilinecek bütün verilerin toplandığı ve kaydedildiği, uygun 
sorgulamalar ile kullanıcıya sunulduğu bir sistemdir. Aynı zamanda, çiftçilerin ve kooperatiflerin tarımsal desteklere olan başvurularını da çevrimiçi olarak yapabileceği bir platform olarak tasarlanmıştır (Küsek, 2017).

TARBIL projesindeki verileri parsellerle ilişkilendirebilmek için tarım parsellerinin sayısallaştırılması çalışmaları da yürütülmüştür. Dolayısıyla SPOT uydu görüntülerinden yapılan sayısallaştırmalar ve Tapu - Kadastro verilerinden derlenen kadastral parsel sınırları ile Türkiye'de 23.1 milyon kadastro parseline karşılık, 32.5 milyon tarım parselinin varlığ tespit edilmiştir ve bu parsellere elektronik kimlik numarası verilmiştir. "Tarım Parseli Bilgi Sistemi" olarak adlandırılan bu çalışmada, parsellerin malik ve kullanıcı bilgileri, tarım parseli kimliği (kimlik numarası, ada, parsel numaraları), parselin rakım, büyük toprak grubu, eğim, organik madde, derinlik ve tohum gibi zirai ve fiziksel verileri, aynı zamanda da verilen desteklerle ilgili veriler bulunmaktadır. Aynı zamanda, 81 ilde 10 bine yakın personelin çalıştırılması ile "Tarım Envanteri Yönetim Sistemi" kurulmuş; personellere canlı görev yönetimi, canlı raporlama ve anlık iletişim gibi işlemler internete bağlı tablet bilgisayarlar ile sağlanmıştır. Görevliler kendi ekranlarından yetkilendirildikleri köyleri görerek bu alanlardaki hayvan, ekipman, ürün, tarım parseli, işletme sayısını sisteme girebilmektedir (TARSEY WEB, 2015).

\section{4 Çalışmanın Amacı}

Oluşturulacak olan KVA'nın, kırsal arazi reformu çalışmalarına yönelik olarak elinde bulundurması gereken onlarca tematik veri seti ve yüzlerce öznitelik bulunmaktadır. Ülkemizde, her veri seti farklı standartlar kullanılarak, farklı kurumlar tarafından üretilmekte ve kullanılmaktadır. Ülkemizin de belirleyici ve katılımcı olduğu uluslararası standartlara ve ülkemizde hâlihazırda kamu eliyle yürütülmekte olan KVA çalışmalarının bilgi birikimi ve süreçlerine uyumlu bir kırsal tematik veri şeması yapısına gereksinim bulunmaktadır.

Bu çalışmada kırsal alanlara yönelik olarak, hem orman ve mera alanlarını, hem de tarım alanlarını kapsayan bir kırsal arazi tematik veri teması oluşturulmuştur. Bu veri teması hem APTS ile eşgüdümlü, hem de İnan'ın önerdiği (2010, s. 159) kırsal arazi kullanımı sorununu çözmeye yönelik bir içeriğe sahiptir.

$\mathrm{Bu}$ çalışmada modellenen KVA veri teması kavramsal modeli, günümüz teknolojilerinden uzak bırakılmamıştır. Yeni veri toplama teknikleri, verilerin anlık ve internet üzerinden, sensörler vasıtasıyla, büyük veri altyapıları mimarisinde toplanmasını ve analiz edilmesini zorunlu kılmaktadır. Bu çalışmada da, sensör teknolojilerinin ve büyük veri anlayışının model ile nasıl bütünleștirileceği gösterilmektedir. Üretilen kırsal alanlar kavramsal modelinde, araziden veri toplayan internete bağlı sensörlerin (akıllı sensörler) kullanımını TUCBS'ye ekleyen bir anlayış bulunmaktadır.

\section{YAPILAN ÇALIŞMALAR}

\subsection{Kırsal Alanlar Veri Teması Kavramsal Modeli}

\subsubsection{Tanım ve kapsam}

$\mathrm{Bu}$ veri temasinın kavramsal modeli, ülkemizdeki kırsal alanlarda bulunan tarım arazilerini, mera arazilerini ve orman arazilerini doğrudan ilgilendirmektedir. Ülkemizde kırsal arazi kullanımları, ayrı ayrı veri altyapılarında ve ayrı yasal dayanaklarla yönetilmektedir. Bütün kırsal arazi kullanımlarının bütünleșik bir veri altyapısı modeli içinde, teknolojinin geldiği yere uygun bir anlayışla yönetilmesi zorunluluğu bulunmaktadır. Kırsal Alanlar Veri Teması Kavramsal Modeli (TR.KR) da, bu istenç doğrultusunda hazırlanmıştır. Türkiye'deki kırsal alanların şematik tarifi Şekil 1'de gösterilmiştir. Şema incelendiğinde, her bir veri setinin hazırlanmasını hükmeden yasal mevzuatı ve devletin kalkınma stratejilerine uygun olarak hazırladığı ya da gerçekleștirdiği projelerden elde ettiği derlenebilir veri setlerini görmek olanaklıdır.

Türkiye'deki orman verileri, Orman Genel Müdürlügü, Tapu Kadastro Genel Müdürlüğü ve bazı durumlarda büyükşehir belediyeleri tarafında üretilmektedir. $\mathrm{Bu}$ farklılıklar, orman verileri arasında sınır çizgisi bakımından tutarsızlıklar oluşturmaktadır. Bu kavramsal modelde, Orman Genel Müdürlügü'nün güncel arazi kullanımına uygun elektronik haritalarındaki veri setlerinden faydalanılmıştır. Orman vasfını yitirmiş 2/B Arazileri için de, Milli Emlak Genel Müdürlügüunnün sınır ve rayiç bedel verileri göz önünde bulundurulmuştur. Arazi kullanım planlamasının "koruma" amacinı düşünerek, yine Orman Genel Müdürlügü'nün orman yangınlarını önleme ve söndürme teçhizatlarını gösteren elektronik harita verileri değerlendirilmiştir.

Türkiye'deki mera varlığı, "Türkiye Geneli Mera Tespit ve Tahdit Çalışmaları" neticesinde tespit edilmiş, 3402 sayılı Kadastro Kanunu'nun 16. maddesi (b) bendi gereği "Kamu Orta Malları Sicilleri" içinde tescil edilmiştir. 4342 sayılı Mera Kanunu'nda belirtilen arazi kullanımı ile ilgili tanımlar da, bu veri şemasına eklenmiştir. Türkiye'nin mera varlığı ve üzerindeki tahsis, işgal, ıslah, hayvan varlığı gibi veriler Mera Bilgi Sistemi'ne (MERBISS) aktarılmıştır. Dolayısıyla, MERBİS içindeki veriler, burada önerilen kırsal alanlar veri teması kavramsal modeline güncelleme ve kontroller sağlandıktan sonra doğrudan aktarılabilir.

Türkiye'deki tarım verileri daha karmaşık bir mevzuat ve uygulama yapısı içermektedir. Kırsal arazi yönetiminin ve arazi kullanımının temelini oluşturan en önemli yasa, 5403 sayll Toprak Koruma ve Arazi Kullanımı Kanunu'dur. Bu kanun uyarınca, arazi kullanım planlamaları, kırsal 
parsellerin gelecek kullanımı ile ilgili kararlar, kırsal parsellerin bölünmesine ilişkin kısıtlamalar ve en önemlisi de kırsal arazilerin sınıflandırılmasına ilişkin teknik detayları içeren süreçler yönetilir. Bu kanuna doğrudan bağlı olan yönetmelikler ve teknik talimatlar, uluslararası standartları da göz önünde bulundurarak arazilerin nasıl sınıflandırılacağını belirtmektedir.

\section{KIRSAL ALANLAR}

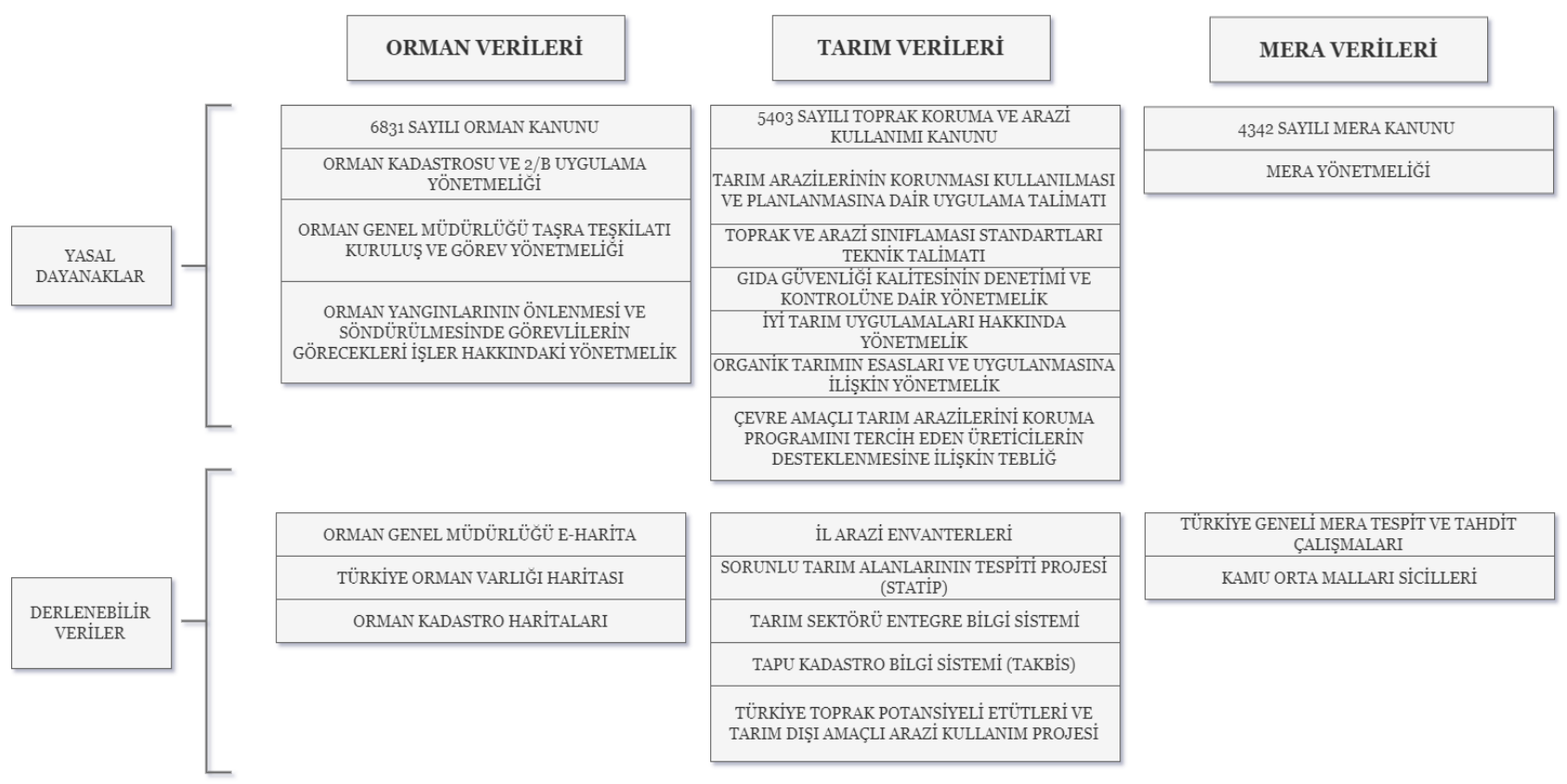

Şekil 1. Türkiye'de Kırsal Alanlarla İlgili Yasal Dayanaklar ve Derlenebilir Veriler

Aynı zamanda, Türkiye'deki tarım ürünlerinin verimliliğini, kalitesini ve güvenliğini artırmak amacıyla Gıda Güvenliği, İyi Tarım Uygulamaları, Organik Tarım, Çevre Amaçlı Tarım Arazilerini Koruma Programı (kıs. ÇATAK) gibi yeni uygulamalar da bu veri şeması içinde düşünülmüştür. Bunun yanı sıra, 5403 sayılı Kanun kapsamında, tarım arazileri üzerindeki tarım dışı faaliyetlerin izlenmesi ve bu konudaki e-devlet üzerinden yapılan başvuruların değerlendirilmesi süreçlerinde gereken iş akışına uygun veriler de bu veri şemasına dahil edilmiştir.

Daha önce bahsedilen TARBİL projesindeki tüm altlıklar düşünüldügünde, sensörlerden elde edilen anlık verilerin de bu büyük veri altyapısı içinde olmazsa olmaz bir yer alması gerektiği anlaşılacaktır. Ancak mevcut durumda TARBİL Projesi için kullanılan sensör verileri, 5403 sayll Kanun'un yüklediği arazi kullanım planlaması ve arazi sınıflandırması sorumluluğunu yeterli derecede karşılamamaktadır. Hâlihazırda toplanan veriler, anlık bitki ve su etkileşimlerini izleyip eylemleri oluşturmak ve meteorolojik izlemelerin yapılmasını sağlamakta olup; mevzuatın ve teknik talimatnamelerin sunduğu arazi sinıflandırması ve arazi kullanım planlamasına altlık olabilecek diğer verileri içermemektedir. Dolayısıyla, TARBİL çalışmalarına toprak sınıflandırmasında önemli yer tutan analitik verileri üretebilecek optik, jeoelektrik, mekanik ve elektrokimyasal sensörlerin de dahil edilmesi gerekmektedir. Bu bağlamda, sunulan bu veri şemasında tüm sensörlere ilișkin özellik tipleri de eklenmiștir.

Internete bağlanan akıllı sensörler, sadece tarım arazilerinde değil, orman ve mera arazilerinde de kullanılabilmektedir. TARBİL projesinin başarılı sensör kullanımı girişimini, diğer kırsal alan türlerinde de desteklemek amaciyla, orman ve mera veri setleri de sensör veri setiyle ilişkilendirilmiştir.

Avrupa'nın INSPIRE Direktifi Ek-3'te bulunan “Toprak Veri Şeması”, hem ülkemizde yürürlükte olan mevzuatlar tarafindan sunulan tanımlara uygunsuzluğu, hem de tarım arazilerimiz hakkında topladığımız veri ve bilgilerin direktifin önerdiği veri setlerinden daha zengin olması gibi nedenlerle ülkemize birebir uyumlu bir șema değildir. Ancak INSPIRE Direktifi, toprak türü sınıflandırması için hem yerel olarak tercih edilen sistemin, hem de Dünya Tarım Örgütü'nün (kls. FAO) sınıflandırma sistemininin kullanılmasını önermektedir. Dolayısıyla 5403 sayılı yasaya göre yapılan sınıflandırmayı içeren veri setinde, hem yerel olarak kullandığımız eski Amerikan sınıflandırmasına dayanan 1984 yllında tamamlanan Türkiye Toprak Envanteri'nde kullanılmıș "Büyük Toprak Grubu" sinifları, hem de FAO'nun World Reference Base (kıs. WRB) toprak sınıfları bir arada öznitelik olarak sunulmuştur. 


\subsubsection{Uygulama şeması}

TR.KR Uygulama Şeması'nın ana bileșeni "KirsalParsel" adlı özellik tipidir. Bu özellik tipi, tarım parsellerini (TarimParseli), mera alanlarını (MeraAlani), orman alanlarında bulunan nesneleri (OrmanNesne) kapsayan diğer özellik tiplerinden hiyerarşik olarak oluşur. Aynı zamanda, kırsal parsellerdeki sensör kullanımından toplanan verileri kapsayan özellik tipi (SensorVeriDegerleri) ile de doğrudan ilişkilendirilmiştir (Şekil 2). Bu uygulama şemasında Avrupa Birliği'nin tarım hibelerine yönetmesi için kurduğu APTS standartlarına göre hazırlanan yerli proje de düşünülmüştür. Şekil 2'nin üst kısımda ilişkilendirilmiş olarak gösterilen ve APTS Fiziksel Bloklarını temsil eden özellik sınıfı sayesinde, APTS projesi bünyesinde sayısallaştırılan fiziksel bloklara ilişkin toprak ve arazi kullanım verilerini bütüncül bir şekilde irdelemek olanaklı olmaktadır. Uygulama şemasını ilgilendiren veri sözlüğü, Ekler kısmındaki Tablo 1'de verilmiştir.

Her tarım parseli "TarimParseli" özellik tipi altında toplanmıştır. Bu özellik tipinde, parselin tarımsal özellikleri ve yetenek sınıfları, tarım dıșı arazi kullanımı, yerel hibeler ve gıda güvenliği sertifikaları işlenmektedir. "tarimsalNitelik" özniteliği, "5403Siniflandirma" veri tipi ile bağdaştırılarak, 5403 sayılı yasaya uygun bir şekilde tarım arazilerimizin nasıl sınıflandırılacağına ilişkin verileri tanımlar. TarimParseli özellik tipi ile ilișkilendirilen diğer öznitelikler ise "GidaSertifikasi, CATAK ve TarimDisiAraziKullanimi" șeklindedir. Sorgulanan tarım parselinde şayet bu uygulamalar yürütülüyorsa, bunlara ilişkin öznitelikleri bir arada görmek olanaklıdır. Adı geçen uygulamaların içindeki öznitelikler, uygulamaların mevzuatlarından ve kayit sistemlerinden derlenmiştir (Şekil 3).

"TarimDisiAraziKullanimi" özellik tipinde belirtilen "basvuruAmaci" özniteliğinin detayları 'TarimDisiKullanimAmaci' kod listesinde belirtilmiştir. $\mathrm{Bu}$ kod listesi hazırlanırken, Tarım Arazilerini Değerlendirme Genel Müdürlüğü'nün Tarım Dışı Otomasyon Sistemi'nden yararlanılmıştır. "CATAK" özellik tipinde belirtilen "kategori" özniteliğinin detayları 'DesteklemeKategorisi' kod listesinde belirtilmiştir. "GıdaSertifikasi” özellik tipinde belirtilen "tip" özniteliğinin detayları da, hâlihazırda bulunan Gıda Güvenliği Bilgi Sistemi'ne dayandırılarak "Sertifikalar" kod listesinde sunulmuştur. Bu sertifikalar, mevzuattaki şartları sağlayan şirketlere verilen organik tarım, iyi tarım uygulamaları ya da gıda güvenliği sertifikaları olarak sıralanır (Şekil 3). TarimParseli ve ilişkili olduğu diğer özellik tiplerine dair veri sözlüğü Ekler kısmında Tablo 2'de sunulmuştur.

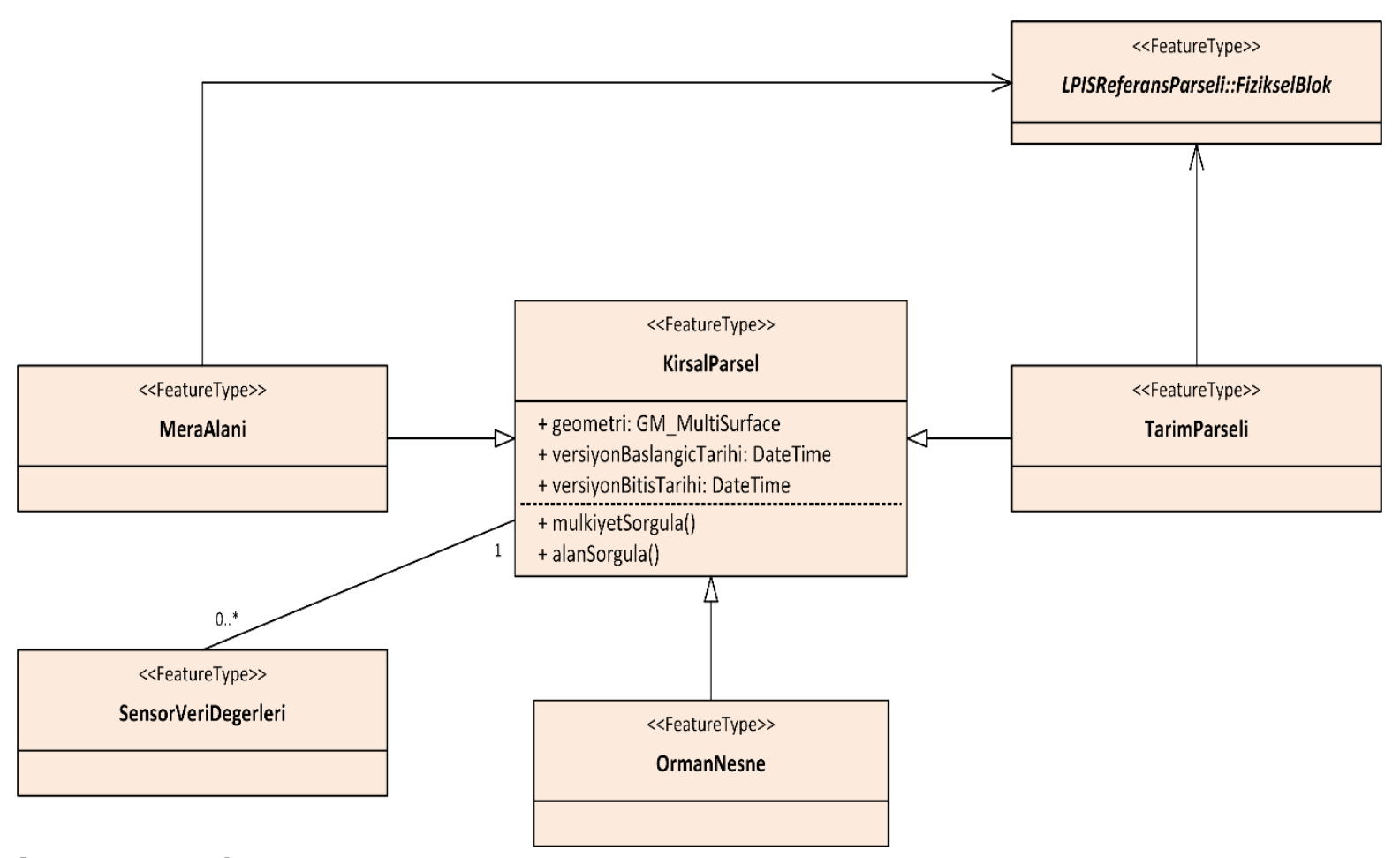

Şekil 2. TR.KR Uygulama Şeması 


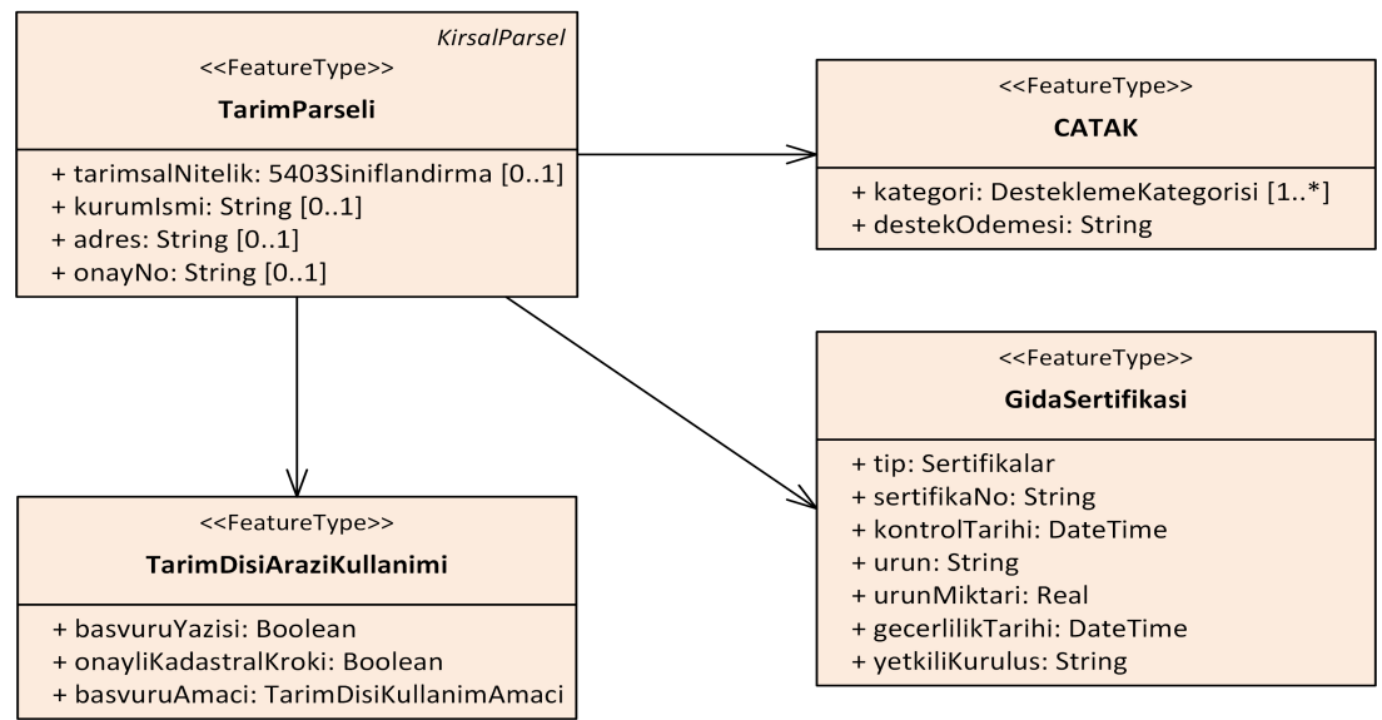

Şekil 3. TarimParseli ve İlişkili Olduğu Özellik Tipleri

Tarım parsellerinin tarımsal niteliğini belirten "5403Siniflandirma" adlı veri tipi, "5403 sayılı yasadaki 7. ve 8. maddeler", kanunun uygulama yönetmeliğinin 8. ve 14. maddeleri, 9 Aralık 2017 tarihinde yürürlüğe giren "Tarım Arazilerinin Korunması, Kullanılması ve Planlanmasına Dair Yönetmelik" ve ilgili uygulama talimatı, "Toprak ve Arazi Sınıflandırması Teknik Talimatı" göz önünde bulundurularak hazırlanmıștır. Bu veri tipinde, sınıflandırma işleminin yapılabilmesi için zorunlu ya da seçmeli olarak elde edilmesi gereken toprakla ilgili öznitelikler bulunmaktadır. Eğer öznitelik bir kod listesi barındırıyorsa, bu da veri şeması içine eklenmiştir (Şekil 4). Hazırlanan kod listeleri, mevzuatın, standartların ya da kullanılan teknolojilerin değişim göstermesi nedeniyle güncellenebilir. $\mathrm{Bu}$ veri tipinde, arazi kullanım planlaması için en çok öneme sahip olan öznitelik "5403AraziTuru" kod listesi ile betimlenen "tur" özniteliğidir. Bu öznitelik aslında, elde edilen diğer veriler aracıllğıyla karar verilen sinıflandırma sonucu olup, arazinin mutlak, marjinal, örtü altı, dikili ya da özel ürün tarım arazisi olması arazi kullanım planlaması kararlarını doğrudan etkilemektedir. Şekil 4'te gösterilen tüm kodlara ilişkin veri sözlüğü, Ekler bölümünde Tablo 3 'te ve 4'te sunulmuştur.

"MeraAlani" özellik tipi, 4342 sayılı Mera Kanunu'nda bulunan tanımlar doğrultusunda hazırlanmıștır. Meralar, kanunun tanımladığı "çayır, mera, yaylak, kışlak" kategorilerine ayrıldığı için, bu alt özellik tiplerinden meydana gelmektedir. Her mera alanı için, otlatma hakkı ve kapasitesi, tahsis bilgileri ve büyükbaş hayvan birimi gibi nitel ve nicel veriler öznitelik olarak eklenmiştir. MERBİS sistemi de benzer bir ișleyișe sahiptir, ancak meralardaki toprak ve su etkileşimlerini izlemek ve hayvanlara ilişkin güncel bilgileri anlık olarak toplayabilmek amacıyla oluşturulmuş dinamik bir altlıktan yoksundur. Dolayısıyla, MeraAlani özellik tipi de sensör verilerinin sunduğu özniteliklere kavuşturulmuştur. Tarım ve Orman Bakanlı̆̆ı'nın meralara da akıllı sistemleri bütünleştirme çalışmalarını projelendirilmesi koşullarında, MERBIS ve sensör verileri bütünleştirilerek modelde önerilen Kırsal Alanlar veri şemasının kapsamına dahil edilebilir (Şekil 5). MeraAlani ve ilişkili özellik tiplerini açıklayan veri sözlüguü, Ekler bölümünde Tablo 5'te sunulmuștur.

"OrmanNesne" özellik tipi, "OrmanAlanlari", "OrmanYangin" ve "2bAlanlari" özellik tiplerini kapsamaktadır. 6831 sayılı Orman Kanunu'nun tanımları ve Orman Genel Müdürlüğü Teşkilat Yönetmeliği'ndeki idari hiyerarşi ve Milli Emlak Genel Müdürlügü'nün 2B Alanları ile ilgili kayıtları göz önünde bulundurularak bu özellik tipleri hazırlanmıștır (Şekil 6). Orman Genel Müdürlüğü'nün hazırladığı Orman Bilgi Sistemi'ndeki (ORBİS) orman kullanımı öznitelikleri ve Orman Mescere Haritaları'nın mescere sınıfları da, kavramsal modelin bu kısmına kod listesi olarak eklenmiştir. "OrmanYangin" özellik tipi, veri altyapısı modelinde geometrik olarak nokta türü nesnelerden oluşmuştur. Bu özellik tipindeki yangın ekipmanı türleri ise, Orman Genel Müdürlüğü'nün e-Harita servislerindeki özniteliklerden derlenmiştir. OrmanNesne ve bağlantılı özellik tiplerini açıklayan veri sözlügü, Ekler bölümünde Tablo $6^{\prime}$ da verilmektedir. 


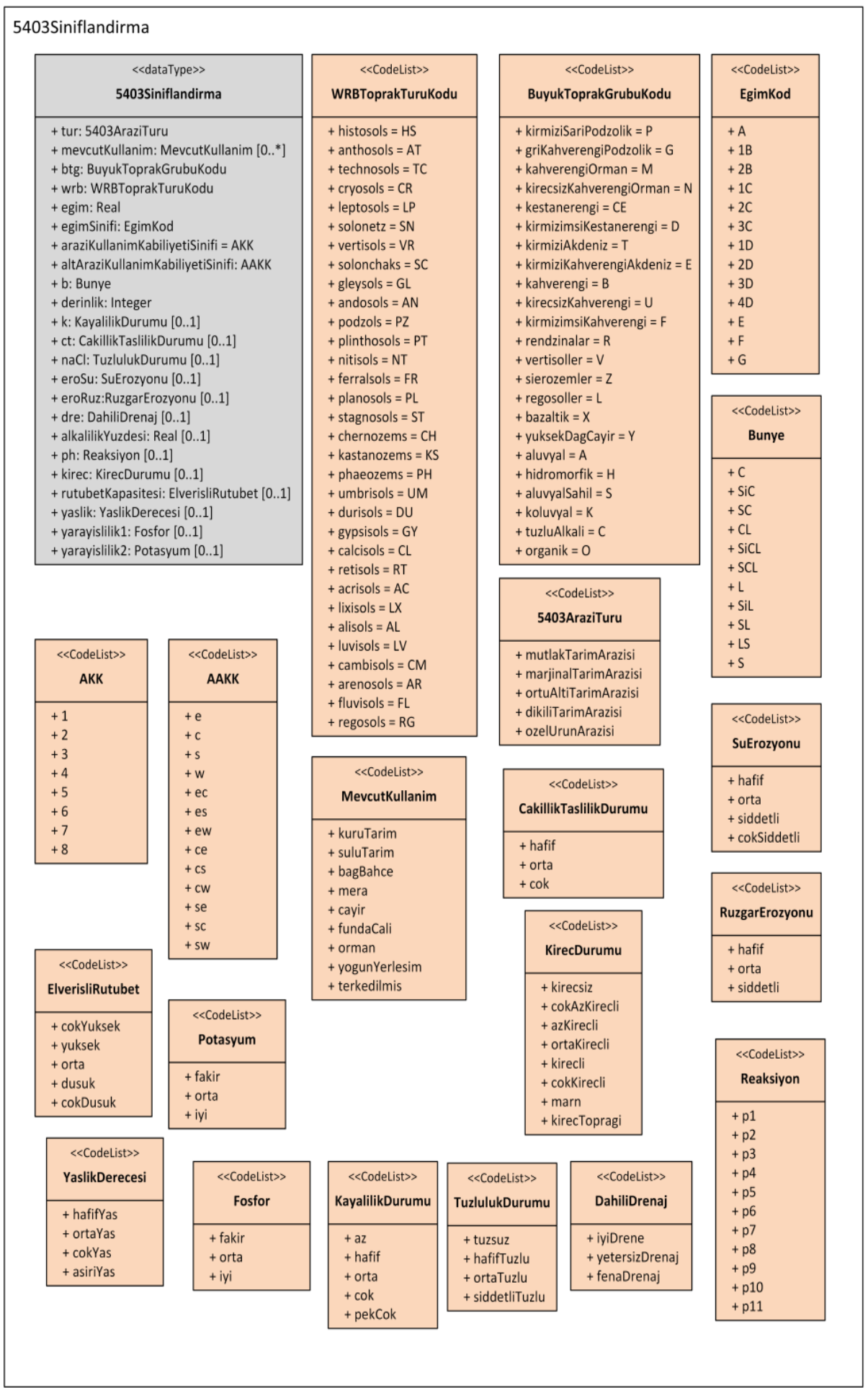
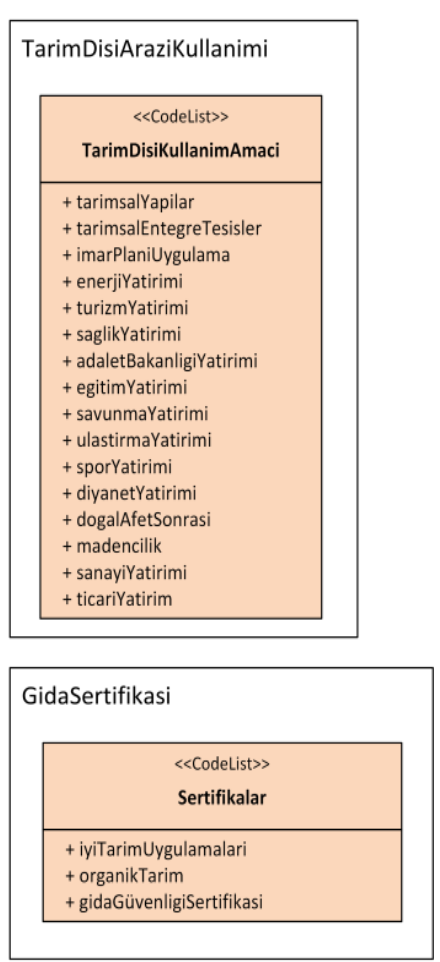

CATAK

\begin{tabular}{|l|}
\hline \multicolumn{1}{|c|}{ 《eCodelist } \\
DesteklemeKategorisi
\end{tabular}

Şekil 4. 5403 Sınıflandırma Veri Tipi ve Kapsadığı Kod Listeleri 


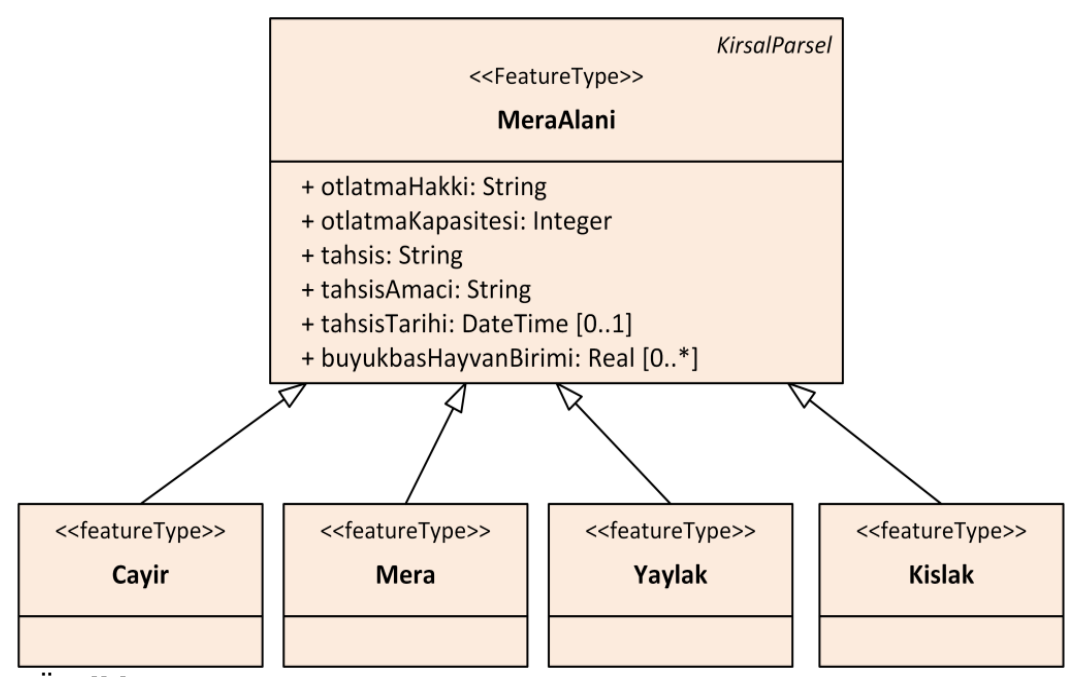

Şekil 5. Mera Alanları Özellik Tipi Şeması

\begin{tabular}{|c|}
\hline \multicolumn{1}{|c|}{ <<FeatureType» } \\
OrmanAlanlari \\
\hline + isim: String \\
+ bolgelD: Integer \\
+ bolgeAdi: String \\
+ isletmeID: Integer \\
+ isletmeAdi: String \\
+ bolmeNo: Integer \\
+ mescere: MescereSinifi \\
+ kullanim: OrmanKullanimi \\
\hline
\end{tabular}

\begin{tabular}{|l|}
\hline \multicolumn{1}{|c|}{ <<CodeList»> } \\
MescereSinifi \\
\hline + verimliOrman \\
+ bozukOrman \\
+ baltalik \\
+ aciklik \\
+ sazlikBataklik \\
+ ozelOrman \\
\hline
\end{tabular}

\begin{tabular}{|l|}
\hline \multicolumn{1}{|c|}{$<<$ CodeList $>$} \\
OrmanKullanimi \\
\hline+ koru \\
$+\mathrm{nbt}$ \\
$+\mathrm{bbt}$ \\
+ maki \\
+ bozukKoru \\
+ diger \\
\hline
\end{tabular}

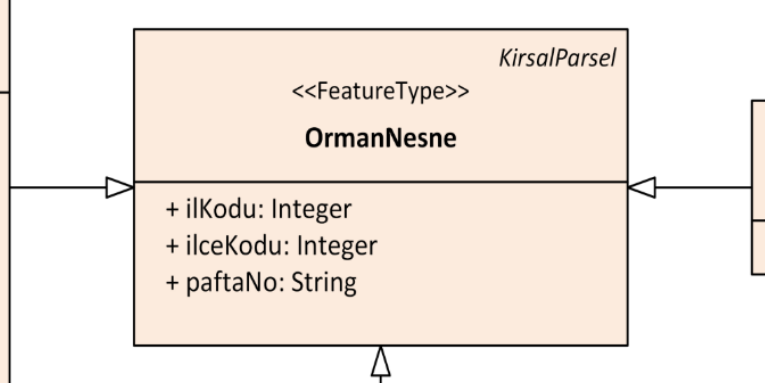

《<FeatureType〉>

2BAlanlari

+ rayicBedel: Real

Şekil 6. Orman Nesne Özellik Tipi İliş̧kisel Şeması ve Kod Listeleri

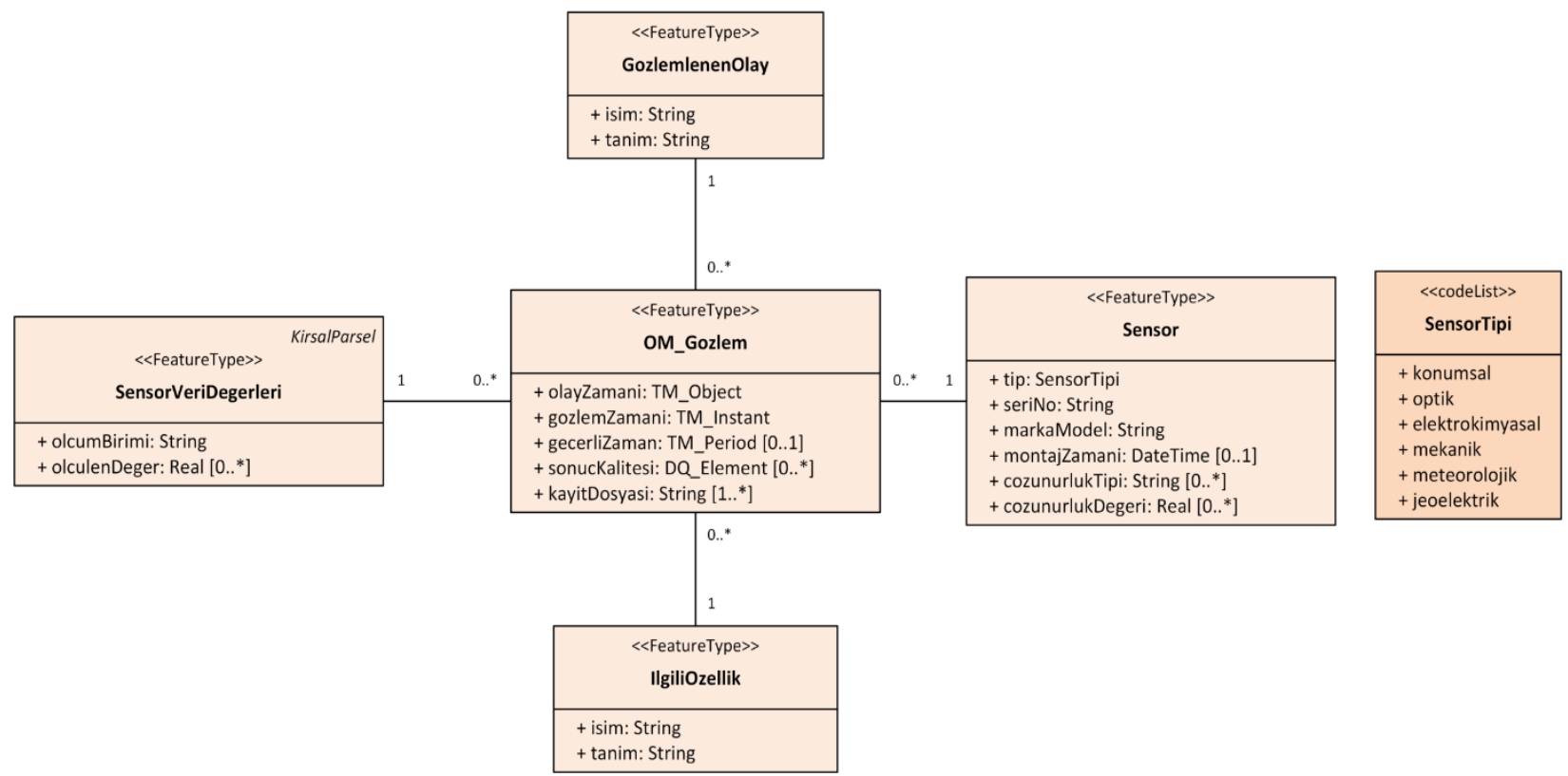

Şekil 7. Sensörler Veri Tipi ve İliş̧kili Kod Listesi 
TR.KR veri teması kavramsal modelinde bütün kırsal parseller SensorVeriDegerleri olarak adlandırılan ve her çeşit kırsal parselden sensör veri akışını sağlayan özellik tipi ile ilişkilendirimiştir (Şekil 7). Bu özellik tipi, ISO 19156 standardının sunduğu çözümlerden uyarlanarak, birçok sensör tipini destekleyen niteliktedir. ISO 19156 standartındaki "Noktasal Gözlem" (Point Observation) anlayışı tercih edilerek, herhangi bir konumda anlı olarak tek bir özelliğin gözlemlenmesi hedeflenmiştir.

İlișkili olan OM_Gozlem özellik tipi anlık olarak gözlemlenen olayı temsil eder. Gözlemlenen olayın özelliklerini GozlemlenenOlay (ObservedPhenomenon) özellik tipi, gözlemlerle ilişkilendirilen gerçek dünya olaylarını IlgiliOzellik (FeatureOfInterest) özellik tipi ve gözlemleyen sensörün özelliklerini de Sensor özellik tipi ile nitelemek olanaklıdır. Sensör tipleri (SensorTipi kod listesi ile nitelenen) ise çok çeşitlidir. Örneğin arazi üzerinde konumsal, optik, elektro-kimyasal, mekanik, meteorolojik ve jeoelektrik sensörler kullanılabilir. $\mathrm{Bu}$ özellik tiplerinde bulunan öznitelikler teknolojik gelişmelere ve gelecekte karşılaşılabilecek yeni gereksinimlere göre esnek olarak tasarlanmıștır. Araziye aplike edilen ya da mobil bir platform üzerinde kurulan sensör istasyonlarında bir ya da birden fazla çeşit sensör kullanılabilir. SensorVeriDegerleri özellik tipinde kaydedilen gözlemlerin ölçü değerleri ve ölçü birimleri saklanır ve bu her bir kırsal parselle ilişkilendirilmiş olur. Kullanıcı bu sayede, sorguladığı parseldeki hâlihazırda mevcut olan sensör verilerini inceleyebilir.

\section{BULGULAR}

Kırsal kalkınma çalışmaları esnasında karşılaşılan arazi kullanımı problemlerinin çözümleri için, güncel dinamik ve yeni teknolojiler ile bütünleşik KVA'ların kullanımına, bu altyapılardan elde edilecek veri ve bilgilerin analizi ışığında yapılacak arazi kullanımı planlamasına ve uygulamasına gereksinim vardır.

Oluşturulacak olan KVA'lar, çok kapsamlı ve geniş hacimli veriler ile beslenmelidir. $\mathrm{Bu}$ denli büyük bir veri altyapısının anlaşılabilmesi için büyük veri kavramının, bu veri altyapısının araziden anlık veri toplayabilmesi için de sensör ve nesnelerin interneti teknolojilerinin irdelenmesi zorunludur. $\mathrm{Bu}$ kadar geniş bilginin toplanabilmesi için insan gücüne ve zaman alıcı süreçlerin işletilmesine ihtiyaç vardır. Bu durum göz önünde bulundurulduğunda, KVA oluşturma ve coğrafi bilgi sistemleri tekniği ile yeryüzünün biyolojik ve fiziksel göstergelerini ve değişimlerini anlık olarak ve her ölçekte, hava

1 TARSEY-TARBİL projeleri INSPIRE ve LPIS girişimlerinin tamamen dişında yürütülmüştür. Kırsal arazilerle ilgili veri ve bilgi üreten bu projelerin, ulusal coğrafi sistemi ağı dışında kalması parçalı ve fotoğrafları, sensörler ve uydu görüntüleri ile tespit etmek olanaklıdır.

$\mathrm{Bu}$ çalıșmada önerilen KVA modelinin, gerçek verilerle ve gerçek arazi çalışmalarıyla test edilmesi zorunluluğu bulunmaktadır. $\mathrm{Bu}$ çalışmada elde edilen veri şeması, bir proje aracılığıyla kamu kurumları çatısı altında tartışılabilir, kamunun beklentilerinin ve diğer bilim insanlarının katkılarının da eklenmesi ile zenginleşebilir.

$\mathrm{Bu}$ çalışmanın önerdiği veri şeması modelinin, daha önceden gerçekleştirilmiş TUCBS v.1, TARSEY ${ }^{1}$ ve şu an çalışmaları yürütülen TUCBS v.2 ile bütünleştirilmesi olanaklıdır. $\mathrm{Bu}$ bütünleştirme sayesinde, hem sensör kullanımı zenginliği sağlanacaktır, hem de mevzuatımıza ve ülkemizin kalkınma hedeflerine uygun, özellikle kırsal arazi kullanımı sorunlarını irdeleyen veri şemaları çerçevesi oluşturulabilir.

INSPIRE Direktifi, her bir kırsal arazi kullanımı tipi için daha küçük ve özel model üretimini önermektedir; böylece sonuç ürünler temaya özgü veri standartlarında üretilebilecektir. Ancak, bu çalışma tüm kırsal arazi kullanımını tek bir model içerisinde irdemektedir. $\mathrm{Bu}$ tercih, bir takım avantajları ve dezavantajları beraberinde getirmektedir. Türkiye'de tüm kırsal alanlar büyükşehir belediyelerinin ve iki adet bakanlığın domine ettiği bir sistem içerisinde yönetilmektedir. Her kurumun farklı sıklıklarda, farklı standartlarda ve farklı ölçeklerde topladıkları bu veriler, bazen aynı araziler için bile farklı nitelikler taşımaktadır. Kurumlar arası tutarlı veri üretiminin sağlanması ve geniş bir veri altyapısının kullanılması daha doğru arazi kullanımı bilgisi sunacaktır. Aksi takdirde, mevcut durumda birlikte çalışılabilirlik karnesi ve yasal bütüncüllüğü zayıf olan ülkemiz için parçalı modeller, güncel olmayan ya da hatalı konumsal bilginin üretilmesine neden olacaktır. Böylesine geniş bir KVA kullanımında karşılaşacağımız bir zorluk ise düzenli bakım süreçlerinin (back-up kontrolleri vb.) maliyetinin artması ve daha geniș disk alanlarına gereksinim duyulması olarak söylenebilir.

INSPIRE Direktifi'nin "Tarım ve Akuakültür" veri temasında etkinlik alanı, site, holding gibi kullanımlarla tarımsal işletmeler nitelendirilmiştir. Ancak bu kullanım biçimi ülkemiz yerel gerçeklerine uygun değildir: (1) tarım ürünleri ve gıda üretimi ile ilgilenen endüstriler ülkemizde toprak sahibi olmak yerine, hammaddelerini geleneksel çiftçilikle uğraşan kır nüfusundan temin etme yolunu tercih ettiği açıktır; (2) geleneksel tarımla uğraşan köylümüzün holding ya da marka oluşturabilecek kooperatifleşme kapasitesi zayıftır; (3) tarım arazilerinin ortaklaşa kullanımı tapu sicil sisteminde kayıt altında değildir. Dolayısıyla APTS projesindeki fiziksel blokların kullanımı tercih edilmiştir.

sürdürülebilir olmayan bir görünümle karşılaşılmasına neden olmaktadır. 
APTS çalışmalarında kullanılan Tarım Parseli özellik tipi Avrupa genelinde tarım parselini tanımlar ve onun konumunu belirtir; tarımsal hibelere uygun olan alanı tespit eder ve çiftçilerin hibe başvuruları ile ilgili bilgileri saklar. Türkiye'de gerçekleştirilen APTS projesi üç aşama geçirmiştir: (1) ortogörüntülerin oluşturulması (24 ay), (2) kalite kontrol (26 ay) ve (3) sayısallaştırma. Türk APTS Projesi, tarımsal hibe verilebilecek arazilerin tespiti için FAO'nun Arazi Örtüsü Sınıflandırma Sistemi'ni (LCCS) yöntem olarak belirlemiştir. $\mathrm{Bu}$ yöntem arazileri yaşam formu, konumsal özellikleri, bitki türleri ve tarım kültürü uygulamaları açısından sinıflandırır (Aslan, 2016; MAF, 2017; Sagris ve diğerleri, 2013; Tarım ve Orman Bakanlığı, 2014). Bu yaklaşım, gıda güvenliği, arazi ve üretim envanterilerinin oluşturulması, toprak analizleri gibi CAP hedefleri için yeterli olmamaktadır. Dolayısıyla oluşturulan TR.KR veri şemasında genişletilmiş bir tarım parseli özellik tipi sunularak tarım bilgi sistemimizin daha çok veri ile beslenmesi hedeflenmiştir. Aynı zamanda da, Aydınoğlu (2009) ve İnan (2010) tarafindan önerilen ve makalenin "Problem Tanımı" alt bölümünde vurgulanan hususları destekleyen bir veri şeması olduğu açıktır.

\section{SONUÇLAR}

$\mathrm{Bu}$ çalışmada, Türkiye geneli oluşturulması gereken arazi kullanımına yönelik KVA'ya esas olacak model önerisi yapılmıştır. Model tasarımında 5403 ve 6360 sayılı kanunların ülkemiz arazi yönetimi ve kullanımı sistematiğine getirdiği yenilikler göz önünde bulundurulmuştur. Bu kavramsal model, ülkemizin oluşturma çalıștığı arazi yönetimi sisteminin (bir diğer deyişle, çok amaçlı kadastronun) kırsal arazi kullanım temasına büyük ölçüde katkı sağlayacaktır. Bu sayede, çok amaçlı kadastronun kullanıcıları, kırsal parsellerin kullanımına ilişkin veri ve bilgileri anlık olarak öğrenebilecek ve özellikle tarımsal üretimde yaşanan darboğazlara ilişkin güncel teknolojiden faydalanarak çözümler üretilebilecektir.

$\mathrm{Bu}$ KVA tasarlanırken, gerek Avrupa INSPIRE Direktifi standartlarından, gerek Türkiye'deki mevcut KVA çalışmalarından faydalanılmıştır. INSPIRE Direktifi'ne göre TUCBS çalışmaları kapsamında tamamlanması gereken kırsal arazi kullanımı ile ilgili tematik veri şemaları hazırlanmıştır. Hazırlanan bu tematik şemanın, INSPIRE Direktifi ile gerek mevzuat, gerek yerel gerçeklerimiz açısından \%100 uyumlu olabilmesi olanaklı değildir. Dünyadan esinlenip, yerel gerçeklerle düşünüldüğünde, uluslararası standartlardan çok uzaklaşmadan, yerel gerçekleri ve mevzuatı da mutlaka göz önünde bulunduran yerli bir KVA üretmek mümkündür. Tasarlanan KVA modeli, hem büyük veri mimarisi, hem de nesnelerin interneti teknolojilerinin sunduğu sensör kullanımı anlayışı ile hareket etmektedir. Dolayısıyla, bu veri şemasının ISO 19156 standardı kullanılarak sensörlerle entegrasyonu sağlanmıştır. Anlık sensör verilerinin kullanılması ile iklim değişimi ve doğal afetlere karşı hassas olan arazi kullanımlarının izlenmesi ve acil eylemlerin oluşturulabilmesi söz konusudur.

Bu model, TARBILL projesinde kullanılan sensör çeşitliliğini artırmakta ve tarım reformu projelerinin gerektirdiği veri çeşitliliğini kapsamaktadır. $\mathrm{Bu}$ büyük KVA mimarisini açıklayan geniş veri sözlükleri, hem standartları ile hem de tanımları ile sunulmuştur.

\section{BILGILENDİRME/TEŞEKKÜR}

Türkiye için arazi kullanımına yönelik konumsal veri altyapısının modellenmesi" başlıklı doktora tezinden bir derlemedir. Bu makalenin daha iyi bir duruma getirilmesi için değerli katkılarını sunan üç anonim hakeme ve dergi editörüne şükranlarımı sunarım. $\mathrm{Bu}$ çalışma, kamu ya da özel sektör kaynaklı fon desteğine sahip değildir.

\section{KAYNAKÇA}

Aslan, M. (2016). LPIS in Turkey. 19 Ocak 2019 tarihinde https://ec.europa.eu/jrc/sites/jrcsh/files/21_S 6_Aslan_ST.pdf adresinden erişildi.

Aydınoğlu, A. Ç. (2009). Türkiye için Coğrafi Veri Değişim Modelinin Geliştirilmesi. Karadeniz Teknik Üniversitesi Doktora Tezi.

Aydınoğlu, A. Ç. ve Yomralıŏlu, T. (2009). Developing Geospatial data specification following INSPIRE with Turkey case. ISPRS International Workshop on Geospatial Data Cyber Infrastructure and Real-time Services with special emphasis on Disaster Management içinde . Hyderabad, India.

Çevre ve Şehircilik Bakanlığı. (2012). Türkiye Ulusal Coğrafi Bilgi Sistemi Standartlarının Belirlenmesi Projesi: TUCBS Kavramsal Model Bileşenleri.

Charvat, K., Junior, K. C., Reznik, T., Lukas, V., Jedlicka, K., Palma, R. ve Berzins, R. (2018). Advanced Visualisation of Big Data for Agriculture as Part of Databio Development. IGARSS 2018 - 2018 IEEE International Geoscience and Remote Sensing Symposium içinde (ss. 415-418). IEEE. doi:10.1109/IGARSS.2018.8517556

Coleman, D. J. ve McLaughin, J. (1998). Defining global geospatial data infrastructure (GGDI): components, stakeholders and interfaces. Geomatica, 52(2), 129-143. doi:https://doi.org/10.5623/geomat-19980021

Durmuş, H., Güneş, E. O., Kırcl, M. ve Üstündağ, B. B. (2015). The design of general purpose 
autonomous agricultural mobile-robot: AGROBOT. 2015 Fourth International Conference on Agro-Geoinformatics (Agrogeoinformatics) içinde (ss. 49-53). IEEE. doi:10.1109/Agro-

Geoinformatics.2015.7248088

European Commission. (2007). Directive 2007/2/EC of the European Parliament and of the council of 14 March 2007 establishing an Infrastructure for Spatial Information in the European Community (INSPIRE). Official Journal of the European Union, 108, 1-14.

Hjelmager, J., Moellering, H., Cooper, A., Delgado, T., Rajabifard, A., Rapant, P., ... Martynenko, A. (2008). An initial formal model for spatial data infrastructures. International Journal of Geographical Information Science, 22(11-12), 1295-1309.

doi:10.1080/13658810801909623

İnan, H. İ. (2010). Arazi İdare Sisteminin Tarım Bileșeni Olarak Konumsal Veri Modeli Geliștirilmesi. Karadeniz Teknik Üniversitesi Doktora Tezi.

Inan, H. I., Sagris, V., Devos, W., Milenov, P., van Oosterom, P. ve Zevenbergen, J. (2010). Data model for the collaboration between land administration systems and agricultural land parcel identification systems. Journal of Environmental Management, 91(12), 24402454. doi:10.1016/j.jenvman.2010.06.030

ISO TC 211/SC. (2011). ISO 19156 Geographic information -- Observations and measurements. doi:10.13140/2.1.1142.3042

Kotsev, A., Schleidt, K., Liang, S., van der Schaaf, H., Khalafbeigi, T., Grellet, S., ... Beaufils, M. (2018). Extending INSPIRE to the Internet of Things through SensorThings API. Geosciences, 8(6), 221. doi:10.3390/geosciences8060221

Küsek, G. (2017). Tarımsal İzleme ve Bilgi Sistemi Projesi. 12 Kasım 2018 tarihinde http://www.gurselkusek.com.tr/_d/TKK_Deste kler14.pdf adresinden erişildi.

Lemmen, C., van Oosterom, P. ve Bennett, R. (2015). The Land Administration Domain Model. Land Use Policy, 49, 535-545. doi:10.1016/j.landusepol.2015.01.014

MAF. (2017). LPIS in Turkey. 19 Ocak 2019 tarihinde http://iacs.tarim.gov.tr/wpcontent/uploads/2018/03/Presentation-LPISin-Turkey.pdf adresinden erişildi.

Masser, I. ve Crompvoets, J. (2015). Implementing INSPIRE in the Member States. I. Masser (Ed.),
Building European Spatial Data Infrastructures içinde. Redlands: ESRI Press.

Pashova, L. ve Bandrova, T. (2017). A brief overview of current status of European spatial data infrastructures - relevant developments and perspectives for Bulgaria. Geo-spatial Information Science, 20(2), 97-108. doi:10.1080/10095020.2017.1323524

Rajabifard, A. ve Williamson, I. P. (2001). Spatial Data Infrastructures: An Initiative to Facilitate Spatial Data Sharing. R. . Tateishi ve D. Hastings (Ed.), Global Environmental Databases - Present Situation and Future Directions içinde (ss. 108136). International Society for Photogrammetry and Remote Sensing.

Resmi Gazete. (2005). Toprak Koruma ve Arazi Kullanımı Kanunu. http://www.mevzuat.gov.tr/MevzuatMetin/1. 5.5403.pdf adresinden erişildi.

Resmi Gazete. (2012). On Dört İlde Büyükşehir Belediyesi ve Yirmi Yedi İlçe Kurulması ile Bazı Kanun ve Kanun Hükmünde Kararnamelerde Değișiklik Yapılmasına Dair Kanun. http://www.mevzuat.gov.tr/MevzuatMetin/1. 5.6360.pdf adresinden erişildi.

Řezník, T., Charvat, K., Lukas, V., Charvat Jr., K., Horakova, Š. ve Kepka, M. (2015). Open Data Model for (Precision) Agriculture Applications and Agricultural Pollution Monitoring. Proceedings of EnviroInfo and ICT for Sustainability 2015 içinde (ss. 97-107). Paris, France: Atlantis Press. doi:10.2991/ict4s-env15.2015 .12

Sagris, V., Wojda, P., Milenov, P. ve Devos, W. (2013). The harmonised data model for assessing Land Parcel Identification Systems compliance with requirements of direct aid and agrienvironmental schemes of the CAP. Journal of Environmental Management, 118, 40-48. doi:10.1016/j.jenvman.2012.12.019

Sang, N., Birnie, R. V., Geddes, A., Bayfield, N. G., Midgley, J. L., Shucksmith, D. M. ve Elston, D. (2005). Improving the rural data infrastructure: the problem of addressable spatial units in a rural context. Land Use Policy, 22(2), 175-186. doi:10.1016/j.landusepol.2003.08.008

Sani, İ. B. (2013). Coğrafi Veri Modelleri Arasında Uygulamaya Yönelik Dönüşüm Algoritmalarının Geliștirilmesi. İstanbul Teknik Üniversitesi Yüksek Lisans Tezi.

Sönmez, İ., Üstündağ, B. B., Bağış, S. ve Çetin, A. (2015). Agro-meteorological data Quality Control System design for Turkey's agricultural 
monitoring and information system (TARBIL). 2015 Fourth International Conference on AgroGeoinformatics (Agro-geoinformatics) içinde (ss. 276-279). IEEE. doi:10.1109/AgroGeoinformatics.2015.7248118

Tarım ve Orman Bakanlığı. (2014). Arazi Parsel Tanımlama Sisteminin (LPIS) Kurulmasına Yönelik AB Projesi Başladı. 19 Ocak 2019 tarihinde https://www.tarimorman.gov.tr/TRGM/Haber /34/Arazi-Parsel-Tanimlama-Sisteminin-_lpis_Kurulmasina-Yonelik-Ab-Projesi-Basladi adresinden erişildi.

TARSEY WEB. (2015). Dr. Gürsel Küsek'in Tarsey (Tarbil) Projesi ile İlgili Röportajı. 22 Kasım 2018 tarihinde https://www.youtube.com/watch?v=kXZ98kw Ma8w adresinden erişildi.

Taşkanat, T. (2016). Çiftçi ve Tarım Arazilerinin Yönetimine Ilişskin İhtiyaç Analizi Yapılması ve Bir Veri Modeli Geliştirilmesi. Erciyes Üniversitesi Yüksek Lisans Tezi.

Tóth, K. ve Kučas, A. (2016). Spatial information in European agricultural data management. Requirements and interoperability supported by a domain model. Land Use Policy, 57, 64-79. doi:10.1016/j.landusepol.2016.05.023

Üstündağ, B. B. ve Şentürk, S. (2015). Parcel based air humidity trend analysis based on meteorological and phenological data obtained from a robo-stations subset of TARBIL's network. 2015 Fourth International Conference on Agro-Geoinformatics (Agro-geoinformatics) içinde (ss. 298-303). IEEE. doi:10.1109/AgroGeoinformatics.2015.7248085

van Oosterom, P. ve Lemmen, C. (2015). The Land Administration Domain Model (LADM): Motivation, standardisation, application and further development. Land Use Policy, 49, 527534. doi:10.1016/j.landusepol.2015.09.032

Yazar, M. F., Özelkan, E. ve Üstündağ, B. B. (2014). Multi-parameter spatial interpolation of solar radiation in heterogeneous structured agricultural areas. 2014 The Third International Conference on Agro-Geoinformatics içinde (ss. 16). IEEE. doi:10.1109/AgroGeoinformatics.2014.6910636 


\section{EKLER}

Tablo 1. KirsalParsel Sınıf Diyagramı Veri Sözlüğü (bkz: Şekil 2)
Öznitelik
Tanım
Durum Tekrar
Tip

$\begin{array}{ccccc}\text { Feature Type: KirsalParsel } & \text { Kirsal parselleri geometric olarak temsil } \\ \text { eder (Çoklu yüzey). } & \mathrm{Z} & 1 & \text { GM_MultiSurface } \\ \text { geometri } & \begin{array}{c}\text { Nesnenin KVA'ya eklendiği ya da KVA'da } \\ \text { güncellendiği zaman. }\end{array} & \mathrm{S} & 1 & \text { DateTime } \\ \begin{array}{c}\text { versiyonBaslangicTarihi } \\ \text { versiyonBitisTarihi }\end{array} & \text { Nesnenin KVA'dan çıkarıldığı zaman. } & \mathrm{S} & 1 & \text { DateTime }\end{array}$

(Z: Zorunlu, S: Seçmeli)

Tablo 2. TarimParseli ve İlişkili Sınıf Diyagramları Veri Sözlüğü (bkz: Şekil 3)

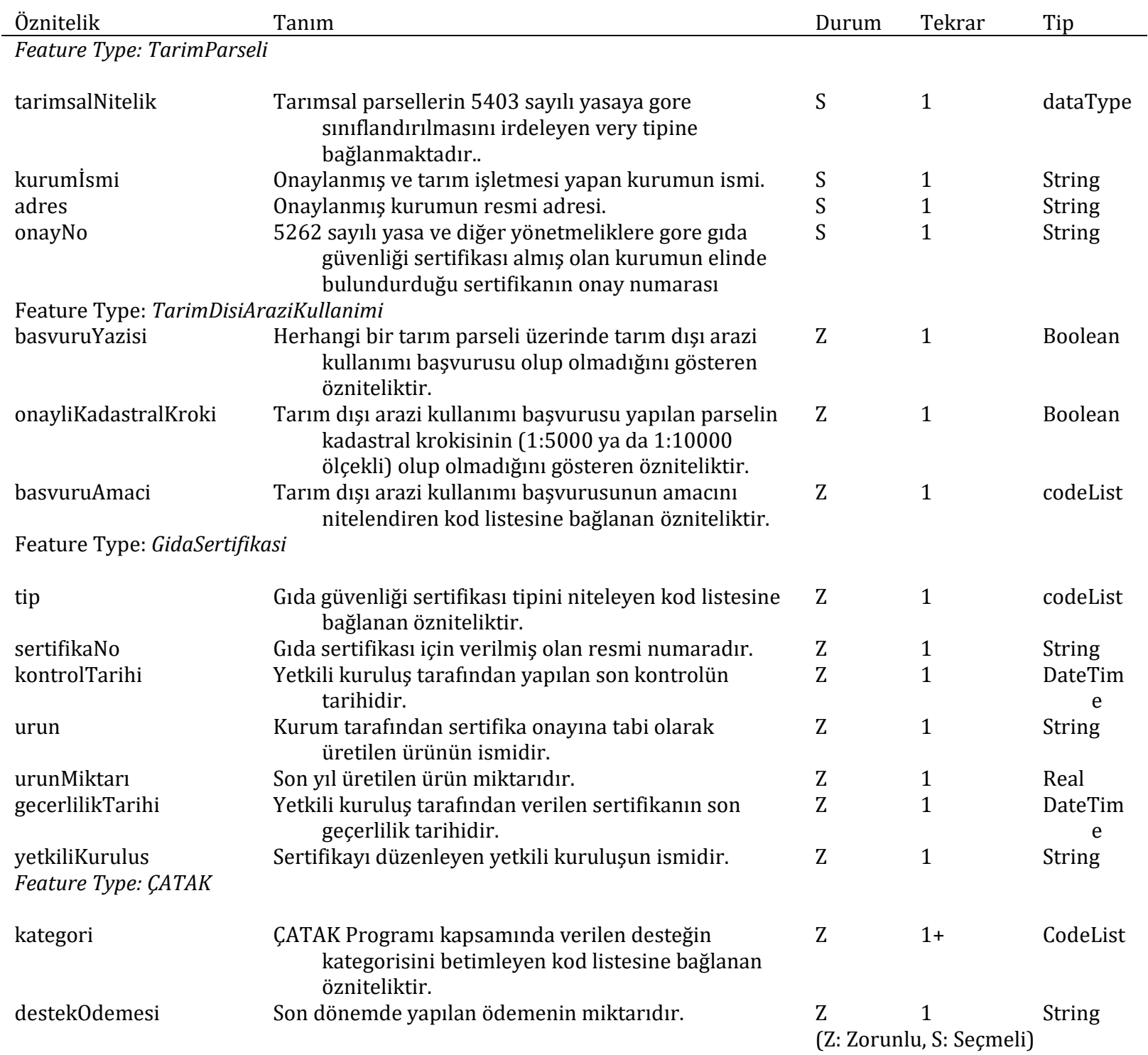


Tablo 3. 5403Siniflandırma Veri Tipi ve Bağlantılı Kod Listeleri (bkz: Şekil 4)

\begin{tabular}{|c|c|c|c|c|}
\hline Öznitelik & Tanım & Durum* & Tekrar & Tip \\
\hline \multicolumn{5}{|l|}{ DataType: 5403Siniflandirma } \\
\hline \multirow{2}{*}{$\begin{array}{l}\text { tur } \\
\text { mevcutKullanim }\end{array}$} & \multirow{2}{*}{$\begin{array}{l}5403 \text { sayılı yasa tanımlarına gore arazi türü. } \\
\text { Yönetmeliklere gore arazinin hâlihazırdaki } \\
\text { kullanımı }\end{array}$} & $\mathrm{Z}$ & 1 & codeList \\
\hline & & $\mathrm{S}$ & $1+$ & codeList \\
\hline btg & $\begin{array}{l}1984 \text { yılında yapılan Toprak Haritalarına } \\
\text { gore Eski Amerikan Sınıflandırmasına } \\
\text { dayanan Büyük Toprak Grubu (BTG). }\end{array}$ & $\mathrm{Z}$ & 1 & codeList \\
\hline \multirow[t]{2}{*}{ wrb } & INSPIRE Direktifi tarafından önerilen & & & \\
\hline & $\begin{array}{l}\text { FAO'nun World Reference Base toprak } \\
\text { grubu. }\end{array}$ & $\mathrm{Z}$ & 1 & codeList \\
\hline \multirow{3}{*}{$\begin{array}{l}\text { egim } \\
\text { egimSinifi }\end{array}$} & Parselin ortalam eğimi. & $\mathrm{Z}$ & 1 & Real \\
\hline & 'Toprak ve Arazi Sinıflaması Teknik & & & \\
\hline & $\begin{array}{l}\text { Şartnamesi'ne gore Arazi Eğim Sınıfi } \\
\text { Kodu. }\end{array}$ & $\mathrm{Z}$ & 1 & codeList \\
\hline \multirow[t]{2}{*}{ araziKullanimKabiliyetSinifi } & $\begin{array}{ccc}\text { Arazinin ekonomik } & \text { kullanımına } & \text { gore } \\
\text { sınıflandırılmasını } & \text { sağlayan } & \text { arazi }\end{array}$ & & & \\
\hline & $\begin{array}{l}\text { kullanım kabiliyet sınıfi. Sinıflar } 1 \text { ile } 8 \\
\text { arasındadır. 1'den 8'e gittikçe kabiliyet } \\
\text { azalır. }\end{array}$ & $\mathrm{Z}$ & 1 & codeList \\
\hline \multirow[t]{2}{*}{ altAraziKullanimKabiliyetSinifi } & Arazi kullanımı kabiliyetini sınırlayan & & & \\
\hline & $\begin{array}{l}\text { özellikler: rüzgar, erozyon, toprak } \\
\text { sorunları vb. }\end{array}$ & $\mathrm{Z}$ & 1 & codeList \\
\hline $\mathrm{b}$ & $\begin{array}{l}\text { Bünye üçgenine gore, araziden alınan toprak } \\
\text { numunesinin test edilmesi sonucunda } \\
\text { elde edilmiş bünye durumu. }\end{array}$ & $\mathrm{Z}$ & 1 & codeList \\
\hline derinlik & $\begin{array}{l}\text { Arazi çalışmalarında ölçülmüş üst toprak } \\
\text { derinliği. }\end{array}$ & $\mathrm{Z}$ & 1 & integer \\
\hline $\mathrm{k}$ & Parsel üzerindeki kayalı yüzey oranıdır. & $\mathrm{S}$ & 1 & codeList \\
\hline ct & Parsel üzerindeki taşlı yüzey oranıdır. & $\mathrm{S}$ & 1 & codeList \\
\hline $\mathrm{naCl}$ & Bitki gelişimini etkileyen tuzluluk oranıdır. & $\mathrm{S}$ & 1 & codeList \\
\hline eroSu & Su erozyonu oranıdır. & $\mathrm{S}$ & 1 & codeList \\
\hline eroRuz & Rüzgâr erozyonu oranıdır. & $\mathrm{S}$ & 1 & codeList \\
\hline dre & Toprağın drenaj kapasitesidir. & $\mathrm{S}$ & 1 & codeList \\
\hline \multirow{2}{*}{$\begin{array}{l}\text { alkalilikYuzdesi } \\
\text { ph }\end{array}$} & Yer değiştirebilir sodium yüzdesi. & $\mathrm{S}$ & 1 & Real \\
\hline & $\begin{array}{l}\text { Toprağın asidik ya da bazik reaksiyon } \\
\text { eğilimidir. }\end{array}$ & $\mathrm{S}$ & 1 & codeList \\
\hline kirecDurumu & $\begin{array}{l}\text { Topraktaki kireç yüzdesini temsil eden kod } \\
\text { listesidir. }\end{array}$ & $\mathrm{S}$ & 1 & codeList \\
\hline rutubetkapasitesi & $\begin{array}{l}\text { Etkin derinlikte toprağın rutubet kapasitesini } \\
\text { temsil eden kod listesidir. }\end{array}$ & $\mathrm{S}$ & 1 & codeList \\
\hline yaslik & Ekili bitkileri etkileyen yaşlık yüzdesidir. & $\mathrm{S}$ & 1 & codeList \\
\hline yarayislilik1 & $\mathrm{P}_{2} \mathrm{O}$ oranıdır. & $\mathrm{S}$ & 1 & codeList \\
\hline yarayislilik2 & $\mathrm{K}_{2} \mathrm{O}$ oranıdır. & $\mathrm{S}$ & 1 & codeList \\
\hline
\end{tabular}


Tablo 4. 5403Siniflandirma Veri Tipine Ait Kod Listeleri Veri Sözlüğü (bkz: Şekil 4)

\begin{tabular}{l} 
Kod Listesi \\
\hline 5403AraziTuru \\
MevcutKullanim \\
BuyukToprakGrubuKodu \\
WRBToprakTuruKodu \\
EgimKod
\end{tabular}

AKK

AAKK

Bunye

KayalilikDurumu

CakillikTaslilikDurumu

TuzlulukDurumu

SuErozyonu

RuzgarErozyonu

DahiliDrenaj

Reaksiyon

KirecDurumu

ElverisliRutubet

YaslikDerecesi

Fosfor

Potasyum

TarimDisiKullanimAmaci

Sertifikalar

DesteklemeKategorisi
Kodlar

mutlakTarimArazisi, marjinalTarimArazisi, ortuAltiTarimArazisi, dikiliTarimArazisi, ozelUrunTarimArazisi

kuruTarim, suluTarim, bagBahce, mera, cayir, fundaCali, orman, yogunYerlesim, terkedilmis

Kodlar, Şekil 4'te görülebilir. Teknik Talimatname'den türetilmiştir.

Kodlar, Șekil 4'te görülebilir. FAO Rehberinden türetilmiştir.

$A(0-2 \%), 1 B(3-4 \%), 2 B(5-6 \%), 1 C(7-8 \%), 2 C(9-10 \%), 3 C(11-12 \%), 1 D(13-14 \%), 2 D$ $(15-16 \%), 3 D(17-18 \%), 4 D(19-20 \%), E(20-30 \%), F(30-45 \%), G(45+\%)$

$1,2,3,4,5,6,7,8$ (Sınıf numarası arttıkça, ekonomik kullanım kapasitesi azalmaktadır. Mevzuatımıza gore ilk dört sınıf tarımsal kullanım için korunması gereken toprakları işaret etmektedir.)

$e, c, s, w$ (erozyon = e, iklim = c, s = toprak, w = islaklık). ec, es, ew, $c e, c s, c w, s e, s c, s w$ (Illk harf baskın sorunu temsil eder. İkincisi ise daha düşük dereceden bir sorundur).

$C$ (kil), SiC (Siltli Kil), SC (Kumlu Kil), CL (Killi Tın), SiCL (Siltli Killi Tın), SCL (Kumlu Killi Tın), $L$ (Tın), SiL (Siltli Tın), SL (Kumlu Tın), LS (Tınlı Kum), $S$ (Kum)

az (yüzeyin \% 0-5), hafif (\% 5-10), orta (\% 10-30), cok (\% 30-50), pekCok (\% 50-90)

hafif (profiling \% 2-10), orta (\% 10-50), cok (\% 50-90)

tuzsuz (\% 0-0.15), hafifTuzlu (\% 0.15-0.35), ortaTuzlu (\% 0.35-0.65), siddetliTuzlu (\%0.65+)

hafif (A Horizonunun \%25'ine kadar), orta (A Horizonunun \%55'ine kadar), siddetli (B Horizonunun \%25'ine kadar), cokSiddetli (B Horizonunun \%25'inden fazlası)

hafif (A Horizonunun \%25-75'i) , orta (B Horizonunun \%25'ine kadar), siddetli (B Horizonunun \%75'ine kadar)

iyiDrene (su kapasitesi normal), yetersizDrenaj (su, toprağı yavaş terk eder), fenaDrenaj (taban suyu yüksek, drenaj çok yavaş)

$p 1(\mathrm{pH}<4.5), p 2$ (4.5-5.0), $p 3$ (5.0-5.5), $p 4$ (5.5-6.0), p5 (6.0-6.5), p6 (6.5-7.0), $p 7$ (7.0-7.5), p8 (7.5-8.0), $p 9$ (8.0-8.5), $p 10$ (8.5-9.0), $p 11(\mathrm{pH}>9.5)$

kirecsiz (0\%), cokAzKirecli (0-2\%), azKirecli (2-4\%), ortaKirecli (4-8\%), kirecli (8-15\%), cokKirecli (15-30\%), marn (30-50\%), kirecTopragi $(+50 \%)$

cokDusuk $(<15 \mathrm{~cm})$, orta $(15-23 \mathrm{~cm})$, yuksek $(23-30.5 \mathrm{~cm})$, cokYuksek $(>30 \mathrm{~cm})$

hafifYas (az etkili), ortaYas (etkili), cokYas (zararlı etkiler), asiriYas (istenmeyen su)

fakir (0.1-0.3 kg / ha), orta (0.3-0.6 kg/ha), iyi ( + 0.6 kg/ha)

fakir (2 kg / ha), orta (2-5 kg/ha), iyi ( + $5 \mathrm{~kg} / \mathrm{ha})$

Kodlar Şekil 4'te görülebilir. Her bir kod, yetkili kurumun bu tarım parselini neden tarım dışı bir kullanıma çıkarmak istediğini temsil eder. Liste, teknik yönetmelikten türetilmiştir.

Bakanlığın yetkilendirdiği gıda denetim kuruluşları tarafından verilen sertifika türüdür: iyiTarimUygulamaları, organikTarim, gidaGuvenligiSertifikasi

birinciKategori (yıllık bitkiler için yapılan ödemeler), kategori2 (parsellerin toprak ve hidrografik yapılarını korumak ve erozyon risklerini önlemek için yapılan ödemelerdir.), kategori3 (çevre dostu tarım teknikleri için yapılan ödemelerdir). 
Tablo 5. MeraAlani Veri Tipi için Veri Sözlüğü (bkz: Şekil 5)

\begin{tabular}{|c|c|c|c|c|}
\hline Öznitelik & Tanim & Durum & Tekrar & Tip \\
\hline \multicolumn{5}{|c|}{ Feature Type: MeraAlani } \\
\hline otlatmaHakki & $\begin{array}{l}\text { Bir veya birden fazla köy veya belediyeye tahsis edilmiş olan } \\
\text { mera, yaylak ve kışlaklarda, çiftçilerin her birinin } \\
\text { müşterek otlatabileceği büyükbaş hayvan birimi sayısıdır. }\end{array}$ & $\mathrm{Z}$ & 1 & String \\
\hline otlatmaKapasitesi & $\begin{array}{l}\text { Belli bir alanda ve eşit zaman aralıkları ile uzun yıllar bitki } \\
\text { örtüsüne, toprak, su ve diğer tabii kaynaklara zarar } \\
\text { vermeden otlatılabilecek büyükbaş hayvan birimi } \\
\text { miktarı. }\end{array}$ & $\mathrm{Z}$ & 1 & integer \\
\hline tahsis & $\begin{array}{l}\text { Meraların münferiden ya da müștereken yararlanılmak üzere } \\
\text { tahsis edildiği yerel yönetim birimini ifade eder. }\end{array}$ & $\mathrm{Z}$ & 1 & String \\
\hline tahsisAmaci & Meraların tahsis amacını ifade eder.. & $\mathrm{Z}$ & 1 & String \\
\hline tahsisTarihi & $\begin{array}{l}\text { Meraların tahsis kararını gösteren resmi belgeyi adres } \\
\text { gösteren özniteliktir. }\end{array}$ & $\mathrm{S}$ & 1 & DateTime \\
\hline $\begin{array}{l}\text { buyukbasHayvanBiri } \\
\text { mi }\end{array}$ & $\begin{array}{l}\text { Meradaki hayvan sayısının, bir büyükbaş hayvan birimi olan } \\
500 \text { kg canlı ağırlığa çevrilerek ifade edilen şeklidir. }\end{array}$ & $\mathrm{S}$ & $1+$ & Real \\
\hline Feature Type: Cayir & $\begin{array}{l}\text { Taban suyunun yüksek bulunduğu veya sulanabilen yerlerde } \\
\text { biçilmeye elverişli, yem üretilen ve genellikle kuru ot } \\
\text { üretimi için kullanılan yerleri anlatır. }\end{array}$ & $\mathrm{Z}$ & $1+$ & featureType \\
\hline Feature Type: Mera & $\begin{array}{l}\text { Hayvanların otlatılması ve otundan yararlanılması için tahsis } \\
\text { edilen veya kadimden beri bu amaçla kullanılan yerleri } \\
\text { anlatır. }\end{array}$ & $\mathrm{Z}$ & $1+$ & featureType \\
\hline Feature Type: Yaylak & $\begin{array}{l}\text { Çiftçilerin hayvanları ile birlikte yaz mevsimini geçirmeleri, } \\
\text { hayvanlarını otlatmaları ve otundan yararlanmaları için } \\
\text { tahsis edilen veya kadimden beri bu amaçla kullanılan } \\
\text { yerleri anlatır. }\end{array}$ & $\mathrm{Z}$ & $1+$ & featureType \\
\hline Feature Type: Kislak & $\begin{array}{l}\text { Hayvanların kış mevsiminde barındırılması ve otundan } \\
\text { yararlanılması için tahsis edilen veya kadimden beri bu } \\
\text { amaçla kullanılan yerleri anlatır. }\end{array}$ & $\mathrm{Z}$ & $1+$ & featureType \\
\hline
\end{tabular}


Tablo 6. OrmanNesne Veri Tipi için Veri Sözlüğü (bkz: Şekil 6)

\begin{tabular}{|c|c|c|c|c|}
\hline Öznitelik & Tanım & Durum & Tekrar & Tip \\
\hline \multicolumn{5}{|c|}{ Feature Type: OrmanNesne } \\
\hline ilKodu & $\begin{array}{l}\text { Orman parselinin sınırları içinde bulunduğu ilin kodunu } \\
\text { ifade eder. }\end{array}$ & $\mathrm{Z}$ & 1 & integer \\
\hline ilceKodu & $\begin{array}{l}\text { Orman parselinin sinırları içinde bulunduğu ilçenin } \\
\text { kodunu ifade eder. }\end{array}$ & $\mathrm{Z}$ & 1 & integer \\
\hline paftaNo & $\begin{array}{l}\text { Orman parselini gösteren } 1: 25.000 \text { ölçekli paftanın } \\
\text { bölümlendirmeye uygun adı. }\end{array}$ & $\mathrm{Z}$ & 1 & String \\
\hline \multicolumn{5}{|c|}{ Feature Type: OrmanAlanlari } \\
\hline isim & Orman parseline ait belirlenmiş isim. & S & $1+$ & string \\
\hline bolgeID & $\begin{array}{l}\text { Orman parselinin yönetiminden sorumlu Orman Bölge } \\
\text { Müdürlüğ̈u'nün kodudur. }\end{array}$ & $\mathrm{Z}$ & 1 & integer \\
\hline bolgeAdi & $\begin{array}{l}\text { Orman parselinin yönetiminden sorumlu Orman Bölge } \\
\text { Müdürlüğ̈̈'nün adıdır. }\end{array}$ & $\mathrm{Z}$ & 1 & String \\
\hline isletmeID & $\begin{array}{l}\text { Orman parselinin yönetiminden sorumlu Orman İşletme } \\
\text { Müdürlügü'nün kodudur. }\end{array}$ & $\mathrm{Z}$ & 1 & integer \\
\hline isletmeAdi & $\begin{array}{l}\text { Orman parselinin yönetiminden sorumlu Orman İşletme } \\
\text { Müdürlügü'nün adıdır }\end{array}$ & $\mathrm{Z}$ & 1 & String \\
\hline bolmeNo & $\begin{array}{l}\text { Orman parselinin denk düştüğü, amenajman haritası } \\
\text { bölmesinin numarasıdır. }\end{array}$ & $\mathrm{Z}$ & 1 & integer \\
\hline mescere & $\begin{array}{l}\text { Orman parselinin meşcere sinıflarına göre kod listesini } \\
\text { betimleyen özniteliktir: verimliOrman, bozukOrman, } \\
\text { baltalik, aciklik, sazlikBaltalik, ozelOrman. }\end{array}$ & $\mathrm{Z}$ & 1 & codeList \\
\hline kullanim & $\begin{array}{l}\text { Orman parselinde bulunan ağaçların kullanım şeklini } \\
\text { belirten kod listesini betimleyen özniteliktir: koru, } \\
\text { nbt (normal baltalık), bbt (Bozuk Baltalık), maki, } \\
\text { bozukKoru, diger. }\end{array}$ & $\mathrm{Z}$ & 1 & codeList \\
\hline \multicolumn{5}{|c|}{ Feature Type: OrmanYangin } \\
\hline ekipman & $\begin{array}{l}\text { Orman yangın veri setinde bulunan ekipmanların kod } \\
\text { listesini betimleyen özniteliktir: techizat, yanginKule, } \\
\text { haberlesmeMerkezi, ilkMudahale, suTemini }\end{array}$ & $\mathrm{Z}$ & 1 & codeList \\
\hline \multicolumn{5}{|c|}{ Feature Type: 2 bAlanlari } \\
\hline rayicBedel & $\begin{array}{l}\text { 2B alanının üzerinde oluşmuş taşınmazlar için Milli Emlak } \\
\text { Genel Müdürlügü tarafından belirlenen rayiç } \\
\text { bedeldir. } \\
\text { Seçmeli) }\end{array}$ & $\mathrm{Z}$ & 1 & Float \\
\hline
\end{tabular}


Tablo 7. Sensor ve Bağlantılı Özellik Tipleri için Veri Sözlügü (bkz: Şekil 7)

\begin{tabular}{|c|c|c|c|c|}
\hline Öznitelik & Tanım & Durum & Tekrar & Tip \\
\hline \multicolumn{5}{|l|}{ Feature Type: Sensor } \\
\hline tip & $\begin{array}{l}\text { Parsele aplike edilmiş sensörlerin tipini sunan kod listesini } \\
\text { betimleyen veri türüdür: konumsal, optik, elektrokimyasal, } \\
\text { mekanik, meteorolojik, jeoelektrik }\end{array}$ & $\mathrm{Z}$ & 1 & codeList \\
\hline seriNo & Parsele aplike edilmiş sensörlerin seri numaralarıdır. & $\mathrm{Z}$ & 1 & String \\
\hline markaModel & Parsele aplike edilmiş sensörlerin marka ve modelidir. & $\mathrm{Z}$ & 1 & String \\
\hline montajZamani & Parselde bulunan sensörün aplikasyon tarihini belirtir. & $\mathrm{S}$ & 1 & DateTime \\
\hline cozunurlukTipi & $\begin{array}{l}\text { Parselde bulunan sensörlerin hangi çözünürlükte veri topladığını } \\
\text { belirtir. }\end{array}$ & S & $1+$ & String \\
\hline cozunurlukDegeri & $\begin{array}{l}\text { Parselde bulunan sensörlerin veri topladığı çözünürlüğün } \\
\text { niceliğini belirtir. }\end{array}$ & $\mathrm{S}$ & $1+$ & Real \\
\hline \multicolumn{5}{|c|}{ Feature Type: SensorVeriDegerleri } \\
\hline olcumBirimi & Sensör tarafindan toplanan verinin ölçüm birimidir. & $\mathrm{Z}$ & 1 & String \\
\hline olculenDeger & Sensör tarafından toplanan verinin sayısal değeridir. & $\mathrm{Z}$ & 1 & Real \\
\hline \multicolumn{5}{|c|}{ Feature Type: GozlemlenenOlay } \\
\hline isim & $\begin{array}{l}\text { Gözlemlenen olayın ismini belirtir. Bu, hava geçirgenliği, toprak } \\
\text { iletkenliği, çiy noktası vb. olabilir. }\end{array}$ & $\mathrm{Z}$ & 1 & String \\
\hline tanim & Gözlemlenen olayın tanımını ve açıklamalarını verir. & $\mathrm{Z}$ & 1 & String \\
\hline \multicolumn{5}{|c|}{ Feature Type: Ilgliozellik } \\
\hline isim & $\begin{array}{l}\text { Burada 'ozellik', gerçek dünyadaki bir olaya karşılık gelmektedir. } \\
\text { Bu öznitelik ise, gözlemlenen olayların gerçek dünyada } \\
\text { ilişkili olduğu olayları anlatmaktadır. }\end{array}$ & $\mathrm{Z}$ & 1 & String \\
\hline tanim & İlgili özelliğin tanımını ve açıklamalarını verir. & $\mathrm{Z}$ & 1 & String \\
\hline \multicolumn{5}{|c|}{ Feature Type: OM_Gozlem } \\
\hline olayZamani & Olayın ilk gerçekleşmeye başladığı andır. & $\mathrm{Z}$ & 1 & TM_Object \\
\hline gozlemZamani & Düzeltmelerden geçirilmiş zamandır. & $\mathrm{Z}$ & 1 & TM_Instant \\
\hline gecerliZaman & $\begin{array}{l}\text { Coğrafi analizler esnasında olayın kullanılmak istenilen } \\
\text { zamanıdır. }\end{array}$ & S & 1 & TM_Period \\
\hline sonucKalitesi & Gözlem kayıtlarının kalitesini tanımlar. & S & $1+$ & DQ_Element \\
\hline kayitDosyasi & Gözlemlerin kaydedildiği log dosyasının ismi ya da URL adresidir. & $\mathrm{Z}$ & $1+$ & String \\
\hline
\end{tabular}

(Z: Zorunlu, S: Seçmeli) 